\title{
Effects of oral calcium supplementation on mineral and acid-base status, energy metabolites, and health of postpartum dairy cows
}

\author{
N. Martinez, ${ }^{*}$ L. D. P. Sinedino, ${ }^{*}$ R. S. Bisinotto, ${ }^{*}$ R. Daetz,† C. Lopera, ${ }^{*}$ C. A. Risco,† K. N. Galvão,† \\ W. W. Thatcher, ${ }^{*} \ddagger$ and J. E. P. Santos ${ }^{*} \ddagger^{1}$ \\ *Department of Animal Sciences, \\ †Department of Large Animal Clinical Sciences, \\ fDH Barron Reproductive and Perinatal Biology Research Program, University of Florida, Gainesville 32611
}

\section{ABSTRACT}

Two experiments were conducted to characterize blood concentrations of minerals and acid-base status after oral dosing of $\mathrm{Ca}$ salts and to determine the effects of oral $\mathrm{Ca}$ on mineral and metabolic status and incidence diseases. The hypotheses were that administration of oral $\mathrm{Ca}$ as $\mathrm{CaCl}_{2}$ and $\mathrm{CaSO}_{4}$ maintains blood total $\mathrm{Ca}$ (tCa) concentrations $\geq 2.125 \mathrm{mM}$ and reduces the incidence of diseases in early lactation. In experiment 1, 18 Holstein cows on the day of calving were assigned to receive a single dose of 0,43 , or $86 \mathrm{~g}$ of $\mathrm{Ca}$ as an oral bolus. Blood was sampled before and after treatments to characterize acid-base status and concentrations of minerals. In experiment 2, 450 Holstein cows considered of low (LRM; normal calving) or high risk (HRM; dystocia, twins, stillbirth, retained placenta, vulvo-vaginal laceration, or a combination of these) of metritis (primiparous-LRM $=84$; primiparous-HRM $=$ 84; multiparous-LRM $=138 ;$ multiparous-HRM $=138$ ) on the day of calving were blocked by parity and then randomly assigned to control, no Ca supplementation; $86 \mathrm{~g}$ of $\mathrm{Ca}$ on d 0 and 1 postpartum (CaS1); or $86 \mathrm{~g}$ of $\mathrm{Ca}$ on $\mathrm{d} 0$ and 1 postpartum followed by $43 \mathrm{~g} / \mathrm{d}$ on $\mathrm{d}$ 2 to 4 postpartum (CaS4). Blood was sampled before and $30 \mathrm{~min}$ after treatment on $\mathrm{d} 0$, and $30 \mathrm{~min}$ after treatments on d 1 to 4 , and d 7 and 10 for determination of concentrations of minerals and metabolites and blood acid-base responses. Disease incidence was evaluated for the first 30 DIM. Concentrations of ionized Ca (iCa) increased for $2 \mathrm{~h}$ in cows supplemented with 43 $\mathrm{g}$ of $\mathrm{Ca}$ and fewer than $8 \mathrm{~h}$ in cows supplemented with $86 \mathrm{~g}$ of $\mathrm{Ca}$. The changes in $\mathrm{iCa}$ concentrations from pretreatment to 30 min after $86 \mathrm{~g}$ of $\mathrm{Ca}$ supplemented on $\mathrm{d} 0$ were $0.11 \pm 0.03 \mathrm{~m} M$ in multiparous cows and

Received October 15, 2015.

Accepted June 5, 2016.

${ }^{1}$ Corresponding author: jepsantos@ufl.edu
$0.25 \pm 0.03 \mathrm{~m} M$ in primiparous cows. Oral Ca reduced the incidence of subclinical hypocalcemia $(\mathrm{SCH} ; \mathrm{tCa}$ $<2.125 \mathrm{mM}$ ) in the first $4 \mathrm{~d}$ in the experiment (control $=69.3 \% ; \mathrm{CaS} 1=57.5 \% ; \mathrm{CaS} 4=34.2 \%)$. Calcium supplementation decreased the prevalence of SCH on d 0 and 1 postpartum in all cows. Stopping oral Ca in $\mathrm{CaS1}$ on d 1 postpartum, however, caused a rebound in $\mathrm{SCH}$ on $\mathrm{d} 2$ to 4 postpartum in primiparous cows. Oral Ca increased the incidence of metritis (control $=22.7 \%$; $\mathrm{CaS1}=34.8 \%$; CaS4 $=32.8 \%$ ), primarily because of an increase in LRM primiparous cows (control $=17.9 \%$; $\mathrm{CaS} 1=35.7 \%$; CaS4 $=42.9 \%)$. Oral $\mathrm{Ca}$ increased morbidity in primiparous cows (control $=38.1 \%$; CaS1 $=61.8 \%$; CaS4 $=60.3 \%$ ) but had no effect on multiparous cows (control $=38.2 \%$; CaS1 $=35.1 \%$; CaS4 $=$ $30.1 \%$ ). Large doses of oral Ca as salts of chloride and sulfate in the first days postpartum should be avoided in primiparous cows and used only in cows at risk of clinical hypocalcemia.

Key words: calcium supplementation, dairy cow, metritis, subclinical hypocalcemia

\section{INTRODUCTION}

Subclinical hypocalcemia (SCH) affects approximately $47 \%$ of the multiparous cows and $25 \%$ of the primiparous cows in dairy farms in the United States (Reinhardt et al., 2011). Recent studies demonstrated that SCH increased concentrations of nonesterified fatty acids in plasma and impaired innate immune function (Martinez et al., 2014). In addition, SCH was associated with increased incidence of uterine and other diseases (Seifi et al., 2011; Martinez et al., 2012), increased risk of culling, and reduced productive and reproductive performance (Chapinal et al., 2012). The increased incidence of uterine diseases observed in cows with $\mathrm{SCH}$ was attributed to a compromised innate immune system (Martinez et al., 2012). Induction of $\mathrm{SCH}$ in nonpregnant nonlactating cows reduced rumen contractions and DMI, and impaired insulin release 
based on decreased concentrations of insulin concurrent with increased concentrations of glucose and fatty acids (Martinez et al., 2014). Also, parathyroid hormone, which is in high concentrations during hypocalcemia, is known to suppress insulin signaling in adipocytes and exacerbate insulin resistance (Chang et al., 2009). Furthermore, cows induced to have SCH had neutrophils with less cytosolic ionized $\mathrm{Ca}$ (iCa), which affected phagocytosis and oxidative burst activities (Martinez et al., 2014). Collectively, it is clear that SCH can have many detrimental effects on health of dairy cows and it plausible to suggest that maintaining adequate circulating iCa concentrations during the first days postpartum might improve energetic status and innate immunity, and reduce the incidence of uterine diseases (Martinez et al., 2012).

Implementation of prepartum acidogenic diets, limited $\mathrm{Ca}$ intake prepartum, and supplementation with vitamin $\mathrm{D}$ have reduced the incidence of clinical hypocalcemia to 3 to $7 \%$; nevertheless, the prevalence of SCH remains high (Reinhardt et al., 2011). Therefore, alternative strategies that complement the use of prepartum feeding of acidogenic salts or other methods of prevention are needed to further minimize the issues associated with early lactation SCH. Supplementation with oral $\mathrm{Ca}$ around calving was implemented originally to prevent clinical hypocalcemia (Thilsing-Hansen et al., 2002). Providing a highly soluble source of oral $\mathrm{Ca}$ induces high concentrations of $\mathrm{iCa}$ in the lumen of the gastrointestinal tract, likely much greater than that typically detected in the vascular compartment (Höller et al., 1988). Thus, the high concentrations of $\mathrm{iCa}$ in the rumen lumen induce a chemical gradient that passively transports iCa from the mucosa through the tight junctions toward the extracellular space in the serosal side, increasing concentrations of $\mathrm{iCa}$ in blood (Bronner, 1987). Multiple studies evaluating administration of oral $\mathrm{Ca}$ concluded that $\mathrm{CaCl}_{2}$ provided a rapid increase in blood iCa for prevention of clinical hypocalcemia (Jorgensen, 1974; Goff and Horst, 1993, 1994). In spite of those findings, studies evaluating the effect of oral administration of different Ca salts have observed contrasting results on blood concentrations of Ca and incidence of peripartum diseases (Oetzel, 1996; Melendez et al., 2003; Oetzel and Miller, 2012).

We hypothesized that oral Ca supplementation during the early postpartum period maintains blood total $\mathrm{Ca}$ (tCa) concentrations $\geq 2.125 \mathrm{mM}$ and reduces the incidence of $\mathrm{SCH}$ and metritis early postpartum, particularly when supplementation is extended for the first $4 \mathrm{~d}$ postpartum. It was also anticipated that the benefits of oral $\mathrm{Ca}$ would be observed in cows regardless of risk of developing metritis. Therefore, the objectives were to characterize the concentrations of $\mathrm{Ca}$ in blood after oral administration of $\mathrm{Ca}$ as $\mathrm{CaCl}_{2}$ and $\mathrm{CaSO}_{4}$, and to evaluate the effect of Ca supplementation and duration of supplementation on the incidence of uterine and other diseases during the early postpartum period in dairy cows considered to be of low or high risk of developing metritis.

\section{MATERIALS AND METHODS}

All procedures involving cows in the experiment were approved by the University of Florida Institute of Food and Agricultural Sciences Animal Research Committee protocol ARC-002-14ANS. The experiments were conducted from September 2013 to February 2014 in a commercial dairy farm in California milking 5,226 cows during the experimental period and with a rolling herd average of $13,635 \mathrm{~kg}$ of $3.5 \%$ FCM.

\section{Experiment 1: Blood Ca Concentrations and Acid- Base Status After Oral Ca Administration}

The experiment was a completely randomized design. Nine primiparous and 9 multiparous Holstein cows without complications at calving (no assistance, singleton live calf, and shed the placenta within $12 \mathrm{~h}$ ) were used in this experiment to characterize blood concentrations of $\mathrm{Ca}$ and $\mathrm{Mg}$ as well as acid-base status with or without supplemental oral $\mathrm{Ca}$ administration. On the day of calving, after colostrum milking, treatments were randomly assigned to cows such that 3 primiparous and 3 multiparous cows each received one dose of 0,43 , or $86 \mathrm{~g}$ of supplemental $\mathrm{Ca}$ as an oral bolus containing a combination of $\mathrm{CaCl}_{2}, \mathrm{CaSO}_{4} \cdot 0.5 \mathrm{H}_{2} \mathrm{O}$, and $\mathrm{CaSO}_{4} \cdot 2 \mathrm{H}_{2} \mathrm{O}$ (Bovikalc; Boehringer Ingelheim Vetmedica Inc., St. Joseph, MO). Jugular venous blood was collected into 3-mL lithium heparin evacuated tubes (Vacutainer, Becton Dickinson, Franklin Lakes, NJ) immediately before and at $0.5,1,2,4,8,12$, and $24 \mathrm{~h}$ after treatment. Samples were analyzed within $5 \mathrm{~min}$ of collection for $\mathrm{pH}$, partial pressure of $\mathrm{CO}_{2}\left(\mathbf{p C O}_{2}\right)$, base excess, and concentrations of $\mathrm{iCa}, \mathrm{HCO}_{3}, \mathrm{Na}$, and $\mathrm{K}$ using a handheld biochemical analyzer (VetScan iSTAT, Abaxis, Union City, CA). In addition, at each sampling point, blood was also sampled into evacuated tubes without anticoagulant, allowed to clot, and placed in ice until processing. Within $4 \mathrm{~h}$ of collection, samples were centrifuged, and serum was harvested and frozen at $-20^{\circ} \mathrm{C}$ until analyses. Serum samples were analyzed for concentrations of tCa and $\mathrm{Mg}$ using an atomic absorption spectrophotometer (AAnalyst 200, Perkin-Elmer Inc., Waltham, MA) and according to a procedure previously described (Martinez et al., 2012). 
Table 1. Ingredient composition and nutrient profile of prepartum and postpartum diets (DM basis)

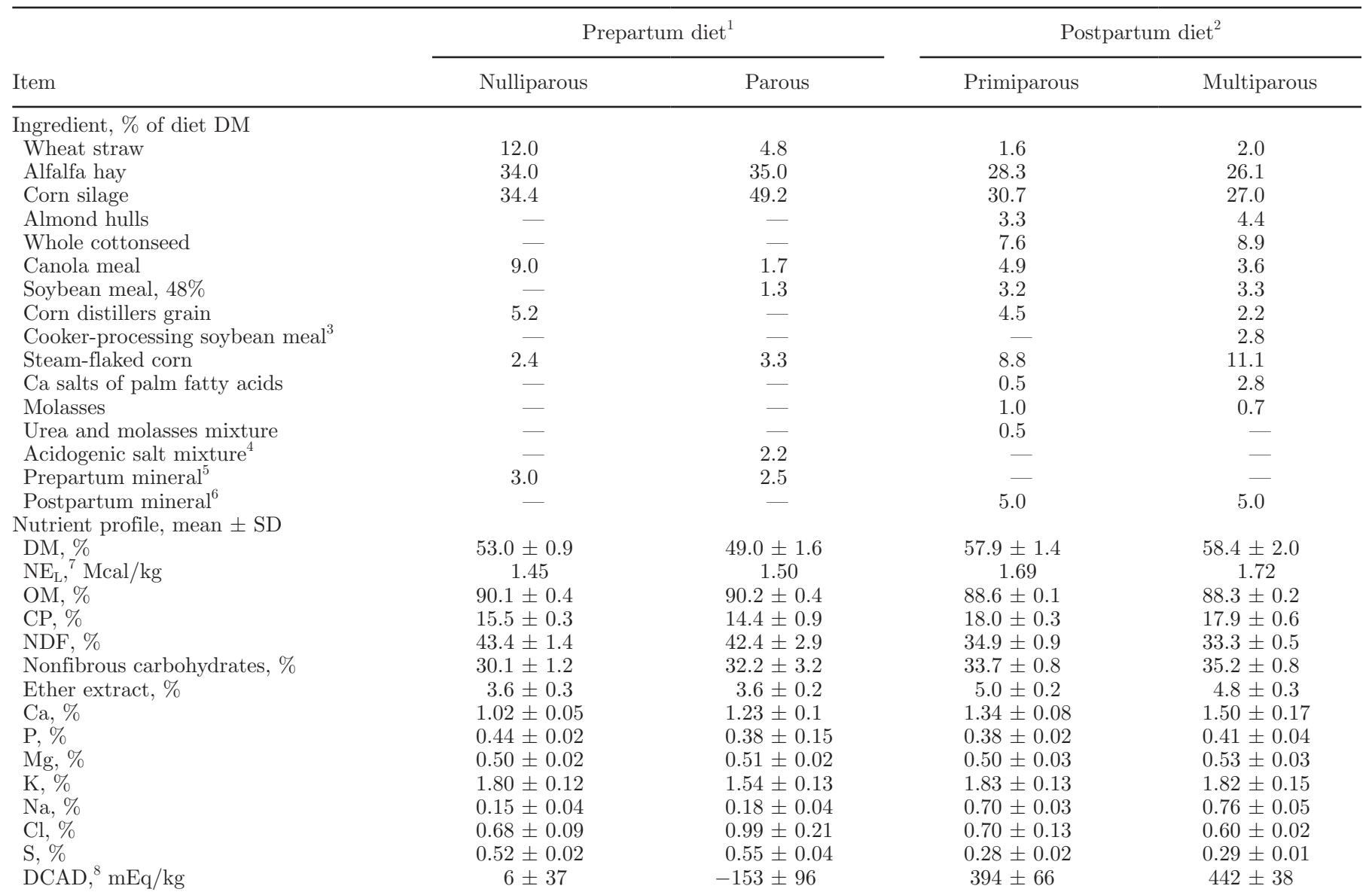

${ }^{1}$ Last $21 \mathrm{~d}$ of gestation.

${ }^{2}$ First 21 d postpartum.

${ }^{3}$ Amino Plus (cooker-processing soybean meal; Ag Processing Inc., Emmetsburg, IA).

${ }^{4}$ Contains (DM basis): $20.8 \%$ corn germ meal, $30.4 \% \mathrm{CaCl}_{2}, 24.5 \% \mathrm{MgSO}_{4} \cdot 7 \mathrm{H}_{2} \mathrm{O}, 20.3 \% \mathrm{CaSO}_{4} \cdot 2 \mathrm{H}_{2} \mathrm{O}$, and $4.0 \% \mathrm{MgO}$.

${ }^{5}$ Contains (DM basis): $27.4 \%$ Prequel-21 (calcium salts of safflower oil fatty acids; Virtus Nutrition, Corcoran, CA), $7.26 \%$ corn germ meal, $26.5 \% \mathrm{MgSO}_{4} \cdot 7 \mathrm{H}_{2} \mathrm{O}, 3.2 \% \mathrm{MgO}, 8.9 \%$ Biophos, $0.6 \% \mathrm{CaCO}_{3}, 3.7 \%$ Zinpro 4-plex (organic sources of Zn, Mn, Cu, and Co; Zinpro Performance Minerals, Eden Prairie, MN), 0.17\% $\mathrm{ZnSO}_{4} \cdot \mathrm{H}_{2} \mathrm{O}, 0.11 \% \mathrm{MnSO}_{4} \cdot \mathrm{H}_{2} \mathrm{O}, 0.6 \%$ Se and I supplement, $5.3 \%$ vitamins A, D, and E concentrate, $13.0 \%$ Omnigen AF (Phibro Animal Health Corp., Teaneck, NJ), 3.4\% Diamond V XPC (yeast culture; Diamond V, Cedar Rapids, IA), and 0.4\% Rumensin 90 (Elanco Animal Health, Eli Lilly and Co, Indianapolis, IN).

${ }^{6}$ Contains (DM basis): $15.0 \%$ corn germ meal, $17.0 \%$ animal protein supplement, $27.9 \% \mathrm{NaHCO}_{3}, 9.3 \% \mathrm{NaCl}, 13.9 \% \mathrm{CaCO}, 9.3 \% \mathrm{MgO}, 1.0 \%$ Zinpro 4-Plex, $0.1 \% \mathrm{ZnSO}_{4} \cdot \mathrm{H}_{2} \mathrm{O}, 0.2 \% \mathrm{MnSO}_{4} \cdot \mathrm{H}_{2} \mathrm{O}, 0.3 \%$ Se and I supplement, $2.7 \%$ vitamins A, D, and E concentrate, 5.0\% Omnigen AF, $1.4 \%$ Diamond V XPC, $0.2 \%$ Rumensin 90.

${ }^{7}$ Calculated at 11 and $13 \mathrm{~kg}$ of DMI/d for the diets fed to prepartum nulliparous and parous cows, respectively, and 15 and $18 \mathrm{~kg}$ DMI/d for the diets fed to postpartum primiparous and multiparous cows, respectively (NRC, 2001).

${ }^{8}$ Calculated using the equation $[(\mathrm{mEq}$ of $\mathrm{Na}+\mathrm{mEq}$ of $\mathrm{K})-(\mathrm{mEq}$ of $\mathrm{Cl}+\mathrm{mEq}$ of $\mathrm{S})]$.

\section{Experiment 2}

Cows, Housing, and Diets. The farm was visited daily by the research team for identification of eligible cows, randomization of cows to treatments, administration of treatments, and diagnosis of diseases. Primiparous and multiparous Holstein cows were housed in separate pens during the pre- and postpartum periods. Pre- and postpartum cows were fed once daily diets formulated to meet or exceed the suggested nutrient concentrations in rations for pre- and postpartum cows (NRC, 2001). Diets were fed as TMR and offered for ad libitum intake. The diet of prepartum parous cows was formulated to have a negative calculated DCAD. The ingredient composition and nutrient content of the diets offered to pre- and postpartum to primiparous and multiparous cows are depicted in Table 1.

Diets were sampled weekly, immediately after feeding, and placed in ice until transported to the laboratory to be frozen. Samples of rations were thawed at room tem- 
perature and dried in an air circulating oven at $65^{\circ} \mathrm{C}$ for $48 \mathrm{~h}$ and moisture loss recorded. Dried samples were then ground to pass a 1-mm screen of a Wiley mill (Thomas Scientific, Swedesboro, NJ). Ground samples were composited for each month and analyzed for DM $\left(105^{\circ} \mathrm{C}\right.$ for $\left.12 \mathrm{~h}\right), \mathrm{OM}\left(512^{\circ} \mathrm{C}\right.$ for $\left.8 \mathrm{~h}\right)$, and $\mathrm{NDF}$ using a heat stable $\alpha$-amylase (Van Soest et al., 1991), N using an automated quantitative combustion digestion method (Leco 628, Leco Corp., St. Joseph, MI), and ether extract. Minerals were analyzed by inductively coupled plasma mass spectrometry in a commercial laboratory (Dairyland Laboratory, Arcadia, WI). The energy density of the diet was estimated by the NRC (2001) as depicted in Table 1.

Definition of Risk of Metritis. The day of calving was experiment $\mathrm{d} 0$. Primiparous $(\mathrm{n}=174)$ and multiparous $(\mathrm{n}=276)$ Holstein cows were evaluated on the day of calving and classified as having low (LRM) or high (HRM) risk of metritis. Cows considered LRM were those with normal calving based on delivery of a live singleton without assistance followed by shedding of the placenta in the first $12 \mathrm{~h}$ after calving. Cows considered HRM were those diagnosed with dystocia, twins, stillbirth, vaginal-vulvar laceration, or retained placenta (or a combination of these) as previously described (Martinez et al., 2012; Vieira-Neto et al., 2016).

Experimental Design and Treatments. The experiment was a randomized block design. The blocking criterion was parity. Randomization sheets were created for primiparous and multiparous cows separately. A HRM cows was matched with a LRM cow based on lactation number and day of calving. Each pair or LRM and HRM was then assigned to 1 of 3 treatments. Treatments were no Ca supplementation or sham bolus administration (control; $\mathrm{n}=150$ cows), $86 \mathrm{~g} / \mathrm{d}$ of $\mathrm{Ca}$ supplementation on d 0 and 1 postpartum $(\mathbf{C a S} 1 ; \mathrm{n}$ $=150 \mathrm{cows})$, or $86 \mathrm{~g} / \mathrm{d}$ of Ca supplementation on $\mathrm{d} 0$ and 1 postpartum, followed by $43 \mathrm{~g} / \mathrm{d}$ on $\mathrm{d} 2,3$ and 4 postpartum (CaS4; $\mathrm{n}=150$ cows). Therefore, within primiparous or multiparous cows, each block contained 6 cows as 3 pairs of one LRM and one HRM each. On experiment $\mathrm{d} 0$, treatments were administered in the morning. From d 1 to 4, treatments were administered in the mornings, between 0600 and $1000 \mathrm{~h}$. Calcium was supplemented using oral boluses as described in experiment 1. A total of 450 cows were enrolled in the experiment, and cows did not receive any additional oral or parenteral $\mathrm{Ca}$ other than the treatments described above and the Ca contained within the diets. The only exception was when a cow developed clinical hypocalcemia, which was diagnosed by the dairy personnel or the research team. Clinical hypocalcemia was defined as a recumbent cow that was unable to stand and walk that responded to intravenous Ca boro- gluconate treatment. Two cases were diagnosed in the experiment and a blood sample was collected before intravenous treatment for later confirmation based on low serum tCa concentration.

Concentration of $\mathrm{iCa}$ and Acid-Base Measures in Blood. Ten blocks of cows ( $\mathrm{n}=60$ cows) were selected at random to evaluate $\mathrm{iCa}$ and acid-base measurements. The 10 blocks represented 10 primiparous cows and 10 multiparous cows per treatment. The sample size was based on the ability to detect a difference of $0.15 \mathrm{mM}$ of iCa between treatments within parity and risk group ( $\mathrm{SD}=0.07 ; \alpha=0.05 ; \beta=0.20$ ). Jugular blood was sampled in 3-mL lithium heparin evacuated tubes on the day of calving immediately before treatment and again at $0.5 \mathrm{~h}$ after treatment on d 0 . Blood was also sampled on d $1,2,3$, and 4 postpartum at $0.5 \mathrm{~h}$ after Ca treatment. Samples were analyzed within 5 min of collection for $\mathrm{pH}, \mathrm{pCO}_{2}$, base excess, and concentrations of $\mathrm{iCa}, \mathrm{HCO}_{3}, \mathrm{Na}$, and $\mathrm{K}$ as described in experiment 1.

Concentrations of $\mathbf{t C a}$ and $\mathbf{M g}$ in Serum. Blood was sampled from all 450 cows by puncture of the coccygeal blood vessels into evacuated tubes without anticoagulant at 0 and $34 \pm 4 \mathrm{~min}$ relative to treatment on the day of calving, and again 30 min after treatment on $\mathrm{d} 1,2,3,4$, and in the morning of $\mathrm{d} 7$ and 10 postpartum. A timer was used to ensure that all samples were collected within expected time from treatment, and control cows were sampled concurrent with cows in CaS1 and CaS4. Samples were allowed to clot and then placed on ice until processing. Within $4 \mathrm{~h}$ of collection, samples were centrifuged and serum was harvested and frozen at $-20^{\circ} \mathrm{C}$ until analysis. Serum samples from all cows on all sampling days were analyzed for concentrations of tCa and $\mathrm{Mg}$ using an atomic absorption spectrophotometer (AAnalyst 200, Perkin-Elmer Inc., Waltham, MA). The procedure was described previously (Martinez et al., 2012). Inter- and intraassay CV were 1.9 and $1.7 \%$ for $\mathrm{Ca}$, and 1.9 and $1.8 \%$ for $\mathrm{Mg}$, respectively.

Concentrations of Nonesterified Fatty Acids, BHB, and Glucose in Serum. Blood was collected from the coccygeal blood vessels into evacuated tubes without anticoagulant as described previously on d 0 , $1,2,3,4,7$, and 10 postpartum from a subset of 50 blocks of cows ( $\mathrm{n}=300), 150$ primiparous cows and 150 multiparous cows, representing 100 controls, 100 CaS1, and 100 CaS4 cows, selected at random for analyses of concentrations of fatty acids, BHB, and glucose. Commercial kits were used to determine serum concentrations of fatty acids (NEFA-C kit; Wako Diagnostics Inc., Richmond, VA; as modified by Johnson and Peters, 1993) and BHB (Wako Autokit 3-HB; Wako Diagnostics Inc.). Inter- and intraassay CV were, 
respectively, 4.4 and $1.5 \%$ for fatty acids, and 9.8 and $1.3 \%$ for BHB. Serum glucose concentrations were determined by colorimetric continuous flow analysis (Gochman and Schmitz, 1972) using an autoanalyzer (Technicon Instruments Corp., Tarrytown, NY). Interand intraassay CV were 3.6 and $1.8 \%$, respectively.

Definition and Diagnosis of Subclinical and Clinical Diseases, and Removal from the Herd. Subclinical hypocalcemia was defined as serum tCa concentrations below $2.125 \mathrm{mM}$. The rectal temperature of cows was measured at $0,1,2,3,4,7$, and 10 DIM using an electronic thermometer (GLA Agricultural Products, San Luis Obispo, CA). Cows with rectal temperature $\geq 39.5^{\circ} \mathrm{C}$ were considered febrile. The uterine discharge of all cows was evaluated at 4, 7, and 10 DIM for the diagnosis of metritis based on the presence of reddish or brownish watery discharge with foul smell (Sheldon et al., 2006). Fever concurrent with metritis was indicative of puerperal metritis. Hyperketonemia was defined as serum BHB concentrations $\geq 1.2 \mathrm{mM}$ in at least one day on $1,2,3,4,7$ or 10 DIM. Cows with serum BHB concentrations $\geq 3.0 \mathrm{~m} M$ in at least one day from 1 to 10 DIM were further considered to have clinical ketosis (McArt et al., 2011). Other diseases within the first 30 DIM such as mastitis, digestive problems (displaced abomasum, watery diarrhea, or bloat), respiratory disease, lameness, and clinical hypocalcemia were diagnosed and recorded for individual cows by the research team and the farm personnel following standardized definitions. Endometritis was assessed at $32 \pm 3$ DIM using the Metricheck device (Simcro, Hamilton, New Zealand) and was defined as vaginal discharge score $>2$, based on the scoring system established by Sheldon et al. (2006). Culling or death and the respective day postpartum of the event were recorded up to 210 DIM.

\section{Statistical Analysis}

Experiment 1. Data in experiment 1 were analyzed by ANOVA for repeated measures with the generalized linear mixed models using the GLIMMIX procedure of SAS (SAS/STAT ver. 9.3, SAS Institute Inc., Cary, NC). Data were tested for the distribution of the residuals and homogeneity of variance, and transformation was performed to achieve normality as needed before analyses. The covariance structure with smallest Akaike's information criterion was selected. The Kenward-Roger method was used to calculate the approximate denominator degrees of freedom for the $F$ tests in the mixed models.

The model to characterize concentrations of minerals and acid-base measures in blood of cows during a 24-h period included the fixed effects of treatment (control, $43 \mathrm{~g}$ of $\mathrm{Ca}, 86 \mathrm{~g}$ of $\mathrm{Ca}$ ), parity (primiparous vs. multiparous), hour of sampling, the interactions between treatment and parity, treatment and hour, parity and hour, and treatment and parity and hour. Cow nested within treatment was the random term to test treatment effects. Orthogonal contrasts were used to determine the effect of $\mathrm{Ca}$ (control vs. $43+86 \mathrm{~g}$ of oral $\mathrm{Ca}$ ) or amount of Ca supplemented ( $43 \mathrm{vs} .86 \mathrm{~g}$ of $\mathrm{Ca}$ ).

Experiment 2. It was hypothesized that Ca supplementation would reduce the incidence of $\mathrm{SCH}$ by $40 \%$ (relative risk of 0.60), which was expected to reduce the incidence of uterine diseases (Martinez et al., 2012). Under that assumption, 135 cows were required per treatment $(\alpha=0.05 ; \beta=0.20)$. For the characterization of blood Ca concentrations within a 24 -h period, it was assumed that oral administration of $\mathrm{Ca}$ would increase blood concentrations of tCa by at least $0.40 \mathrm{mM}$. Given that the SD of serum tCa is $0.2 \mathrm{mM}$ (Martinez et al., 2012), then 6 cows per treatment would be needed to detect differences $(\alpha=0.05 ; \beta=0.20)$.

Binary data such as incidence and prevalence of diseases were analyzed by a log-Poisson regression with robust error variance using the GENMOD procedure of SAS (SAS/STAT ver. 9.3) according to McNutt et al. (2003) and Spiegelman and Hertzmark (2005), or by logistic regression using the GLIMMIX procedure of SAS (SAS/STAT ver. 9.3). The models included the fixed effects of treatment (control, CaS1, CaS4), risk group (HRM, LRM), parity (primiparous, multiparous), and the interactions between treatment and risk group, treatment and parity, and treatment and risk group and parity. For repeated measurements within the same experimental unit such as daily prevalence of $\mathrm{SCH}$, the models also included the fixed effects of time, and interactions of treatment and time, and the random effect of cow nested within treatment. Measurements taken before treatment on d 0 were used as covariates during analyses. Orthogonal contrasts were used to evaluate the effect of Ca supplementation (control vs. CaS1 + CaS4), duration of Ca supplementation (CaS1 vs. CaS4), interaction between $\mathrm{Ca}$ supplementation and risk of metritis, interaction between duration of $\mathrm{Ca}$ supplementation and risk of metritis, interaction between Ca supplementation and parity, and interaction between duration of Ca supplementation and parity.

Continuous data such as concentrations of minerals, metabolites, and measures of acid-base status were tested for the distribution of the residuals and homogeneity of variance, and transformation was performed to achieve normality as needed before analyses. Continuous data were analyzed using the generalized linear mixed models using the GLIMMIX procedure of SAS (SAS/STAT ver. 9.3) fitting a Gaussian distribution. The models included the fixed effects of treatment, risk group, parity, and the interactions between treatment and risk 
group, treatment and parity, and treatment and risk group and parity. For repeated measurements within the same experimental unit, the models also included the fixed effects of time, and interactions of treatment and time, and the random effect of cow nested within treatment. Measurements taken before treatment on d 0 were used as covariates during analyses. The covariance structure with smallest Akaike's information criterion was selected. The Kenward-Roger method was used to calculate the approximate denominator degrees of freedom for the $F$ tests in the mixed models. Pairwise comparisons among treatments or treatment and time were adjusted by the method of Tukey.

Time to event such as such as survival by 210 DIM was analyzed with Cox's proportional hazard regression model using the PHREG procedure of SAS (SAS/ STAT ver. 9.3) with a model that included the effects of treatment, risk group, parity, and the interactions between treatment and risk group, treatment and parity, and treatment and risk group and parity. Nonsignificant interactions $(P>0.10)$ were dropped from the final models.

Statistical significance was considered at $P \leq 0.05$, and tendency was considered at $P \leq 0.10$.

\section{RESULTS}

\section{Experiment 1. Blood Ca Concentrations and Acid-Base Status}

Pretreatment concentration of iCa in blood did not differ among treatments, and averaged 1.08, 1.07, and $1.11 \pm 0.03 \mathrm{~m} M$ for 0,43 , and $86 \mathrm{~g}$ of oral Ca, respectively (Figure 1A). After oral administration of $\mathrm{Ca}$, blood iCa concentrations increased and were greater $(P$ $<0.01)$ in cows receiving oral Ca compared with cows receiving $0 \mathrm{~g}$ of $\mathrm{Ca}$. Concentrations of $\mathrm{iCa}$ in the hours following treatments averaged 1.08, 1.12, and $1.15 \pm$ $0.01 \mathrm{mM}$ for 0,43 , and $86 \mathrm{~g}$ of oral $\mathrm{Ca}$, respectively (Figure 1A). The maximum change in iCa with respect to the pretreatment concentrations was observed at 0.5 $\mathrm{h}$ after bolus administration and averaged $-0.02 \pm 0.02$ $\mathrm{m} M$ for $0 \mathrm{~g}$ of $\mathrm{Ca}, 0.07 \pm 0.02 \mathrm{~m} M$ for $43 \mathrm{~g}$ of $\mathrm{Ca}$, and $0.11 \pm 0.02 \mathrm{~m} M$ for $86 \mathrm{~g}$ of Ca. Although the increase in iCa lasted fewer than $2 \mathrm{~h}$ for cows receiving $43 \mathrm{~g}$ of $\mathrm{Ca}$, and fewer than $8 \mathrm{~h}$ for cows receiving $86 \mathrm{~g}$ of $\mathrm{Ca}$, the average $\mathrm{iCa}$ concentrations for the 24 -h period did not differ $(P=0.12)$ with dose of Ca.

Pretreatment concentrations of serum tCa did not differ $(P=0.66)$ among treatments and averaged 2.11 $\pm 0.06 \mathrm{~m} M$ (Figure 1B). However, cows receiving 43 or $86 \mathrm{~g}$ of oral $\mathrm{Ca}$ had greater $(P<0.03)$ serum tCa concentrations for the next $24 \mathrm{~h}$ compared with cows receiving $0 \mathrm{~g}$ of oral $\mathrm{Ca}$. Concentrations of tCa for the $24 \mathrm{~h}$ evaluated averaged 2.09, 2.13, and $2.20 \pm 0.02 \mathrm{mM}$ for 0,43 , and $86 \mathrm{~g}$ of oral Ca, respectively (Figure 1B). Cows supplemented with $86 \mathrm{~g}$ of oral Ca had greater $(P$ $=0.05) \mathrm{tCa}$ concentrations compared with cows supplemented with $43 \mathrm{~g}$ of oral $\mathrm{Ca}$. The maximum changes from the pretreatment concentrations of tCa observed after administration of 0,43 , and $86 \mathrm{~g}$ of Ca were 0.00 , 0.12 , and $0.21 \pm 0.03 \mathrm{~m} M$, respectively. These differences were observed at $0.5 \mathrm{~h}$ for cows receiving $43 \mathrm{~g}$ of $\mathrm{Ca}$, and at $1 \mathrm{~h}$ in cows receiving $86 \mathrm{~g}$ of $\mathrm{Ca}$.

Serum concentrations of $\mathrm{Mg}$ did not differ with treatment, and averaged $0.94,0.94$, and $0.95 \pm 0.02 \mathrm{~m} M$ for 0,43 , and $86 \mathrm{~g}$ of $\mathrm{Ca}$, respectively (Figure 1C). Blood $\mathrm{pH}$ did not differ with administration of oral $\mathrm{Ca}$ and averaged $7.488,7.483$, and $7.483 \pm 0.012$ for 0,43 , and $86 \mathrm{~g}$ of $\mathrm{Ca}$, respectively (Figure $2 \mathrm{~A}$ ). In addition, blood $\mathrm{pCO}_{2}$ was not influenced by administration of oral Ca, averaging $44.2,42.4$, and $41.4 \pm 1.1 \mathrm{~m} M$ for 0,43 , and $86 \mathrm{~g}$ of $\mathrm{Ca}$, respectively (Figure 2B). Blood concentrations of $\mathrm{HCO}_{3}$ or base excess were not affected by administration of oral $\mathrm{Ca}$ and averaged 33.0, 31.7, and $31.2 \pm 1.2 \mathrm{mM} \mathrm{HCO}_{3}$ and $9.4,8.2$, and $7.8 \mathrm{mM}$ base excess for 0,43 , and $86 \mathrm{~g}$ of $\mathrm{Ca}$, respectively (Figure $2 \mathrm{C}$ and 2D). Concentrations of $\mathrm{Na}$ in blood increased $(P<0.01)$ in cows treated with oral Ca from 1 to $4 \mathrm{~h}$ after treatment administration, after which cows that received $86 \mathrm{~g}$ of $\mathrm{Ca}$ had blood $\mathrm{Na}$ concentrations returned to pretreatment concentrations at $24 \mathrm{~h}$ (Figure $2 \mathrm{E})$. The mean concentrations blood $\mathrm{Na}$ were 144.2 , 145.6 , and $145.9 \pm 0.4 \mathrm{mM}$ for cows receiving 0,43 , and $86 \mathrm{~g}$ of $\mathrm{Ca}$, respectively (Figure 2E). Administration of oral $\mathrm{Ca}$ did not affect blood concentrations of $\mathrm{K}$, averaging 4.03, 4.17, and $4.10 \mathrm{~m} M \mathrm{~K}$ for 0,43 , and 86 $\mathrm{g}$ of oral Ca, respectively (Figure $2 \mathrm{~F}$ ).

\section{Experiment 2}

Of the 450 cows enrolled in experiment 2, 3 pairs of primiparous cows ( $3 \mathrm{LRM}$ and $3 \mathrm{HRM}$ ) were removed and not considered for statistical analyses because the 3 LRM cows were found to have retained placenta after enrollment had taken place. Therefore, 444 cows remained in the experiment to evaluate health, survival, and concentrations of minerals in blood. The same 6 primiparous cows were also removed from the analyses of serum concentrations of fatty acids, BHB, and glucose. Therefore, 294 cows remained for those analyses.

The proportion of HRM cows having dystocia $(47.7 \%)$, twins $(30.2 \%)$, stillbirth $(23.9 \%)$, retained fetal membranes $(32.0 \%)$, or vulvo-vaginal laceration $(18.5 \%)$ did not differ among treatments. Only 2 of the 444 cows developed clinical hypocalcemia, both in the 

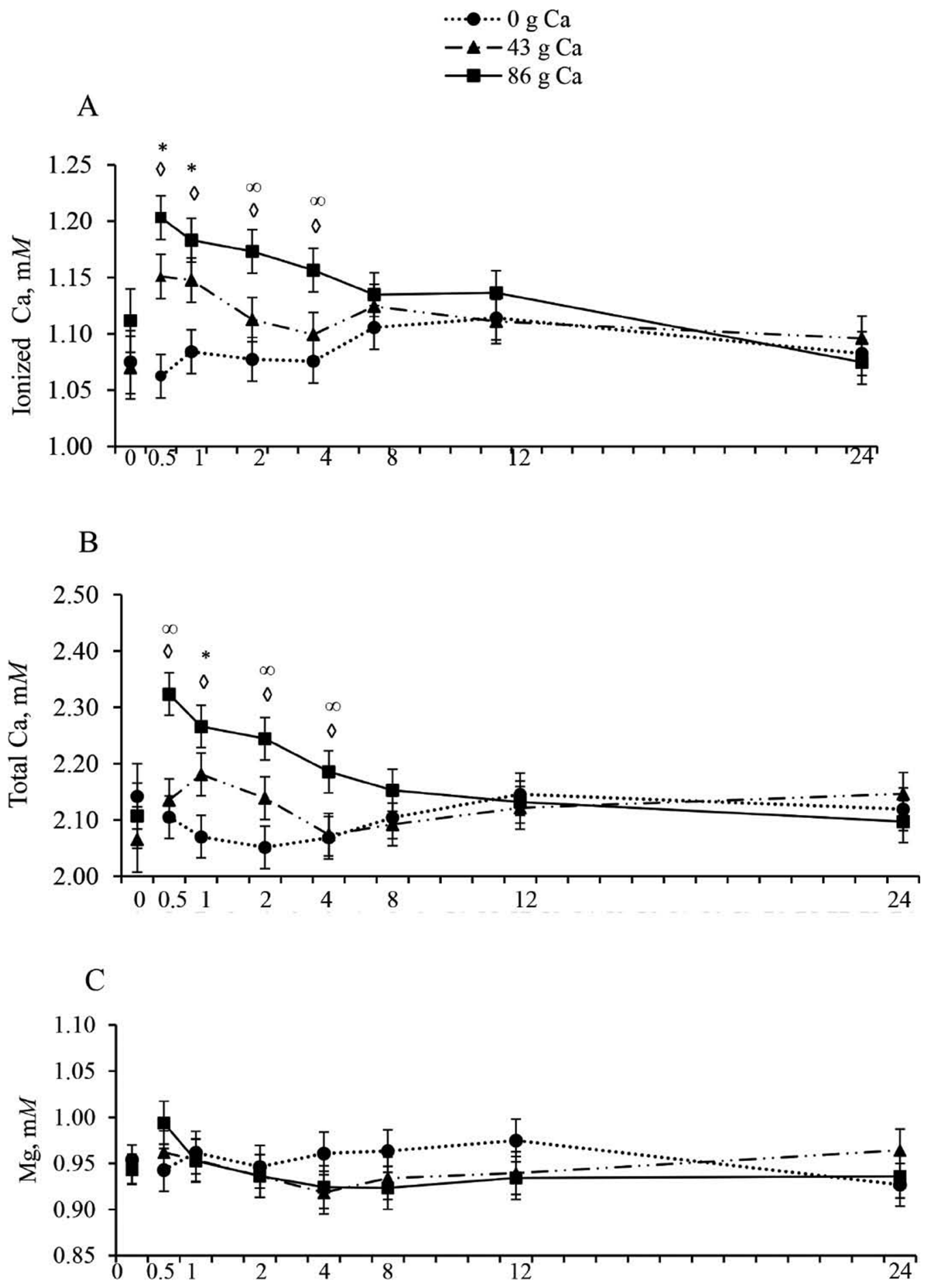

Hour relative to oral Ca administration

Figure 1. Characterization of blood ionized Ca (A), serum total Ca (B), and serum $\mathrm{Mg}(\mathrm{C})$ concentrations after oral supplementation with 0,43 , or $86 \mathrm{~g}$ of oral $\mathrm{Ca}$ in experiment 1 . Treatments were applied to 18 Holstein cows, 3 primiparous and 3 multiparous cows per treatment on the day of calving. Panel A: effect of oral Ca $[0$ vs. $(43+86 \mathrm{~g}): P<0.01]$, effect of amount of oral Ca $(43 \mathrm{vs} .86 \mathrm{~g}, P=0.12)$, parity $(P<0.01)$, hour $(P<0.01)$, and interaction between treatment and hour $(P=0.02)$. Panel B: effect of oral Ca $(P=0.03)$, effect of amount of oral Ca $(P=$ $0.05)$, parity $(P=0.02)$, hour $(P<0.15)$, and interaction between treatment and hour $(P=0.05)$. Panel C: effect of oral Ca $(P=0.61)$, effect of amount of oral Ca $(P=0.97)$, parity $(P=0.02)$, hour $(P<0.49)$, and interaction between treatment and hour $(P=0.25)$. Within hour, 43 $\mathrm{g}$ of oral Ca differ from $0 \mathrm{~g}$ of oral Ca $(P<0.05)$. $\diamond$ Within hour, $86 \mathrm{~g}$ of oral Ca differs from $0 \mathrm{~g}$ of oral Ca $(P<0.05)$. $\infty$ Within hour, $86 \mathrm{~g}$ of oral Ca differs from $43 \mathrm{~g}$ of oral Ca $(P<0.05)$. Error bars depict SEM. The pooled SEM for ionized Ca, total Ca, and $\mathrm{Mg}$ were, respectively, $0.02,0.04$, and 0.02 . 

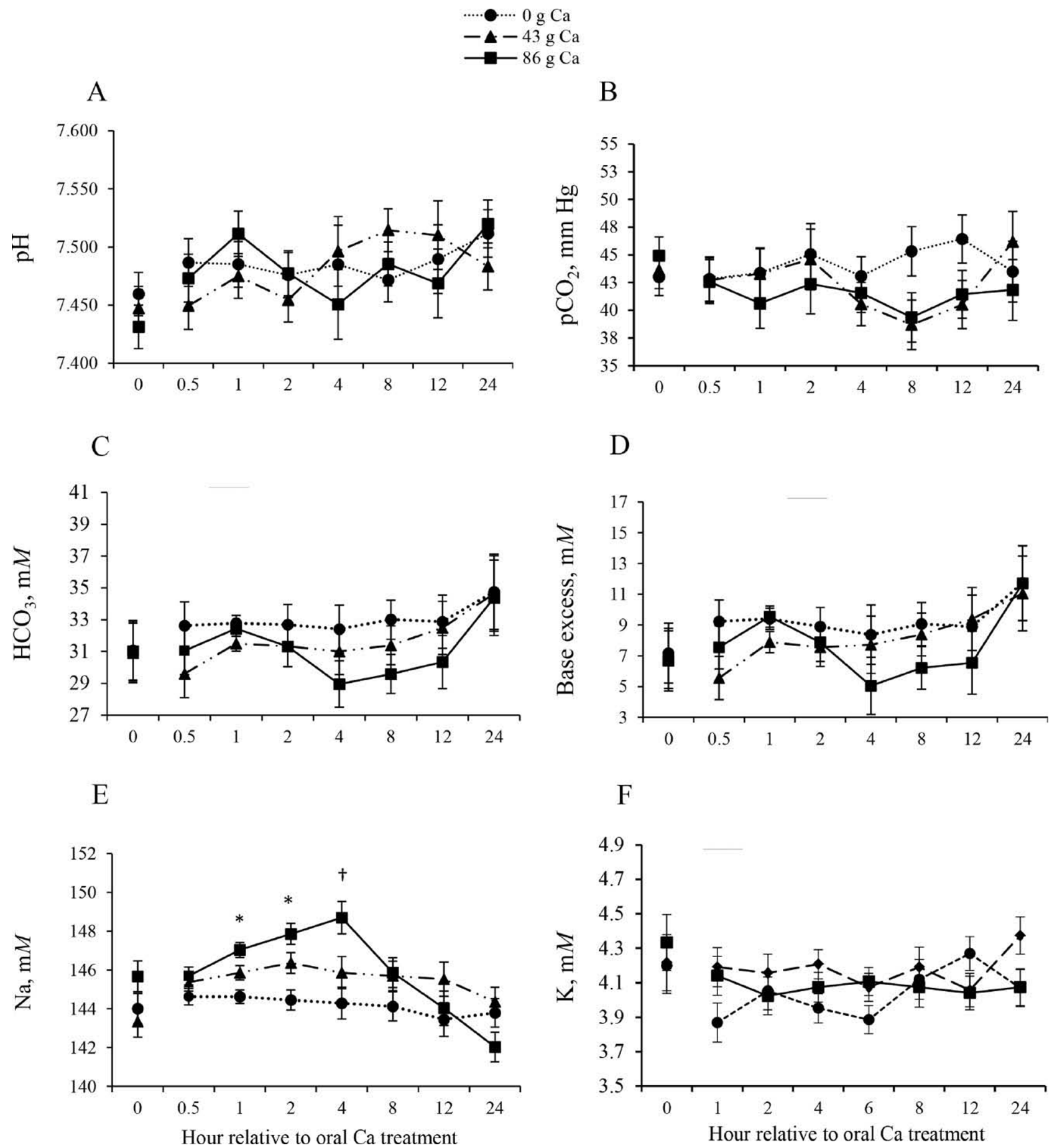

Figure 2. Characterization of blood acid-base measurements after oral supplementation with 0,43 , or $86 \mathrm{~g}$ of oral Ca in experiment 1 . Treatments were applied to 18 Holstein cows, 3 primiparous and 3 multiparous cows per treatment on the day of calving. $\mathrm{Blood}_{\mathrm{pH}}(\mathrm{A})$, $\mathrm{pCO} \mathrm{C}_{2}$ (partial pressure of $\left.\mathrm{CO}_{2} ; \mathrm{B}\right), \mathrm{HCO}_{3}^{-}(\mathrm{C})$, base excess (D), Na (E), and $\mathrm{K}(\mathrm{F})$. Panel A: effect of oral Ca [0 vs. (43 + 86); $\left.P=0.85\right]$, effect of amount of Ca (43 vs. $86 ; P=0.98)$, parity $(P=0.82)$, hour $(P=0.29)$, interaction between treatment and hour $(P=0.55)$. Panel B: effect of oral Ca $(P=0.12)$, effect of amount of oral Ca $(P=0.56)$, parity $(P<0.01)$, hour $(P=0.73)$, and interaction between treatment and hour $(P$ $=0.74)$. Panel $\mathrm{C}$ : effect of oral $\mathrm{Ca}(P=0.28)$, effect of amount of oral Ca $(P=0.74)$, parity $(P=0.03)$, hour $(P=0.02)$, interaction between treatment and hour $(P=0.65)$. Panel D: effect of oral Ca $(P=0.21)$, effect of amount of oral Ca $(P=0.73)$, parity $(P=0.05)$, hour $(P=0.02)$, and interaction between treatment and hour $(P=0.59)$. Panel E: effect of oral Ca $(P<0.01)$, effect of amount of oral Ca $(P=0.64)$, parity $(P$ $=0.06)$, hour $(P<0.01)$, interaction between treatment and hour $(P=0.03)$. Panel F: effect of oral Ca $(P=0.16)$, effect of amount of oral Ca $(P=0.19)$, parity $(P<0.01)$, hour $(P=0.64)$, and interaction between treatment and hour $(P=0.10)$. ${ }^{*}$ Within hour, administration of 43 or $86 \mathrm{~g}$ of oral Ca differs from $0 \mathrm{~g}$ of oral $\mathrm{Ca}(P<0.05)$. †Within hour, $86 \mathrm{~g}$ differs from 0 and $43 \mathrm{~g}$ of oral Ca $(P<0.05)$. Error bars depict SEM. The pooled $\mathrm{SEM}$ for $\mathrm{pH}, \mathrm{pCO}_{2}, \mathrm{HCO}_{3}$, base excess, $\mathrm{Na}$, and $\mathrm{K}$ were, respectively, $0.02,2.20,1.48,1.63,0.67$, and 0.11 . 
control treatment, and these 2 cows were the only to receive intravenous $\mathrm{Ca}$ borogluconate as therapy. The 2 cows remained in the study.

\section{Blood Acid-Base Measures}

Pretreatment blood $\mathrm{pH}$ did not differ among treatments and averaged $7.482 \pm 0.013$. Calcium supplementation or duration of supplementation did not affect blood pH, which averaged 7.491, 7.491, and 7.491 土 0.006 for control, CaS1 and CaS4, respectively (Table $2)$. An interaction $(P<0.01)$ between Ca supplementation and parity was observed for $\mathrm{HCO}_{3}$ because primiparous cows supplemented with $\mathrm{Ca}$ had reduced blood $\mathrm{HCO}_{3}$ compared with controls, whereas in multiparous cows, Ca supplementation increased $\mathrm{HCO}_{3}$ concentrations compared with controls. In addition, tendencies for interaction between $\mathrm{Ca}$ supplementation and parity were observed for base excess $(P=0.07)$ and $\mathrm{pCO}_{2}(P$ $=0.10)$. Supplemental Ca reduced blood base excess and $\mathrm{pCO}_{2}$ compared with controls in primiparous cows, whereas the opposite response was observed in multiparous cows (Table 2 ).

\section{Concentrations of Blood iCa and Serum tCa, and Incidence and Prevalence of $\mathrm{SCH}$}

Pretreatment blood $\mathrm{iCa}$ concentrations did not differ among treatments. However, the concentrations of blood iCa increased $(P<0.01)$ by $0.18 \pm 0.02 \mathrm{mM}$ within $0.5 \mathrm{~h}$ for $\mathrm{CaS} 1$ and $\mathrm{CaS} 4$ cows receiving $86 \mathrm{~g}$ of oral $\mathrm{Ca}$ compared with a slight decrease of $-0.02 \pm$ $0.02 \mathrm{~m} M$ in control cows. An interaction between $\mathrm{Ca}$ supplementation and parity was observed because the increase in blood iCa was less $(P<0.01)$ in multiparous $(0.11 \pm 0.01 \mathrm{~m} M)$ than in primiparous cows $(0.25$ $\pm 0.01 \mathrm{~m} M)$ after supplementation on experiment $\mathrm{d} 0$ (Figure 3). The concentrations of $\mathrm{iCa}$ for the first $4 \mathrm{~d}$

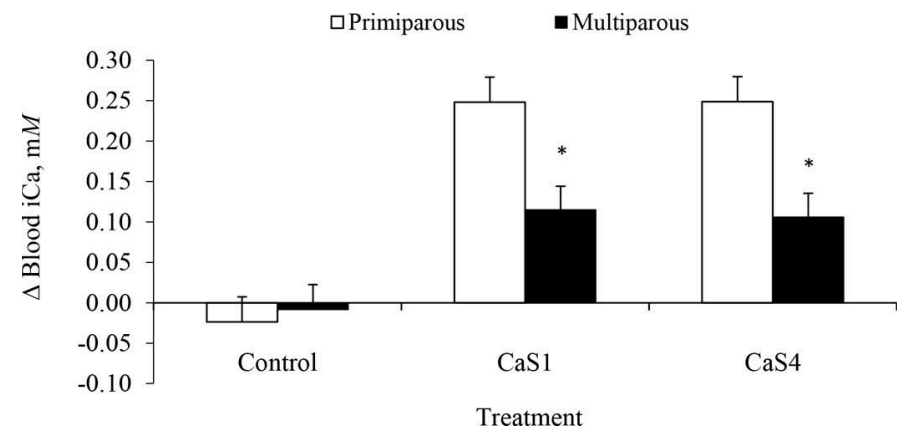

Figure 3. Change in blood ionized $\mathrm{Ca}(\mathrm{m} M)$ between the pretreatment concentrations and concentrations at $0.5 \mathrm{~h}$ after the first dosing with $\mathrm{Ca}$ on $\mathrm{d} 0$ in experiment 2 . Blood was collected and analyzed from a subset of 10 randomly selected blocks representing 60 Holstein cows, 10 primiparous and 10 multiparous cows per treatment in experiment 2. Control cows received no supplemental oral Ca. CaS1 received $86 \mathrm{~g}$ of oral $\mathrm{Ca}$ at 0 and $1 \mathrm{~d}$ postpartum. CaS4 received $86 \mathrm{~g}$ of oral $\mathrm{Ca}$ at 0 and $1 \mathrm{~d}$ postpartum, and $43 \mathrm{~g}$ at 2,3 , and $4 \mathrm{~d}$ postpartum. Effect of Ca supplementation [control vs. $(\mathrm{CaS} 1+\mathrm{CaS} 4) ; P<0.01)$, parity $(P<0.33)$, interaction between $C a$ supplementation and parity $(P<$ $0.01) .{ }^{*}$ Within treatment, primiparous and multiparous cows differ $(P$ $<0.01)$. Error bars depict SEM. The pooled SEM was 0.030.

postpartum were greater $(P<0.01)$ in supplemented cows $(\mathrm{CaS} 1=1.16 \pm 0.01 ; \mathrm{CaS} 4=1.21 \pm 0.01 \mathrm{mM})$ compared with controls $(1.10 \pm 0.01 \mathrm{mM})$, and this effect was observed in both primiparous and multiparous cows (Figures $4 \mathrm{~A}$ and $4 \mathrm{~B}$ ). In addition, cows in CaS4 had greater $(P<0.01)$ concentration of blood iCa compared with CaS1 cows. The percent of tCa in the ionized form was greater $(P<0.05)$ in Ca supplemented cows compared with controls $(49.9,51.5$, and $51.0 \pm 0.5 \%$ of tCa as iCa for control, CaS1, and CaS4, respectively).

Primiparous cows had greater $(P=0.01)$ tCa concentrations before any Ca supplementation compared with multiparous cows $(2.19 \pm 0.01$ vs. $2.10 \pm 0.01 \mathrm{mM})$. Similarly, LRM cows had greater $(P<0.01)$ concentrations of tCa in serum than HRM cows $(2.17 \pm 0.01$ vs.

Table 2. Acid-base measurements in the first $4 \mathrm{~d}$ postpartum according to parity and treatment from cows in experiment $2^{1}$

\begin{tabular}{|c|c|c|c|c|c|c|c|c|c|c|c|c|}
\hline \multirow[b]{2}{*}{ Item } & \multicolumn{3}{|c|}{ Primiparous } & \multicolumn{3}{|c|}{ Multiparous } & \multirow[b]{2}{*}{ SEM } & \multicolumn{5}{|c|}{$P$-value ${ }^{2}$} \\
\hline & Control & CaS1 & $\mathrm{CaS} 4$ & Control & CaS1 & $\mathrm{CaS} 4$ & & $\mathrm{CaS}$ & Dur & Par & $\begin{array}{c}\mathrm{CaS} \\
\times \mathrm{Par}\end{array}$ & $\begin{array}{l}\text { Dur } \\
\times \text { Par }\end{array}$ \\
\hline $\mathrm{pH}$ & 7.489 & 7.490 & 7.484 & 7.493 & 7.492 & 7.498 & 0.008 & 0.99 & 0.97 & 0.32 & 0.74 & 0.45 \\
\hline $\mathrm{HCO}_{3}, \mathrm{~m} M$ & 32.6 & 31.6 & 30.5 & 31.9 & 33.7 & 34.8 & 0.7 & 0.58 & 0.89 & 0.70 & $<0.01$ & 0.15 \\
\hline Base excess, $\mathrm{m} M$ & 9.0 & 7.7 & 7.3 & 9.8 & 10.9 & 10.6 & 0.8 & 0.68 & 0.68 & $<0.01$ & 0.07 & 0.95 \\
\hline $\mathrm{PCO}_{2},{ }^{3} \mathrm{~mm} \mathrm{Hg}$ & 42.8 & 40.3 & 40.9 & 43.4 & 44.7 & 42.8 & 0.9 & 0.25 & 0.47 & $<0.01$ & 0.10 & 0.14 \\
\hline
\end{tabular}

${ }^{1}$ Control $=$ no Ca supplementation postpartum; CaS1 = cows received $86 \mathrm{~g}$ of Ca per day on d 0 and 1 postpartum; CaS4 = cows received 86 $\mathrm{g}$ of Ca per day on d 0 and 1 postpartum, and then $43 \mathrm{~g}$ of Ca per day on d 2, 3, and 4 postpartum. Blood was sampled from a subset of 10 randomly selected blocks representing 60 cows, 30 primiparous and 30 multiparous cows, resulting in 10 cows per treatment within each parity. Samples were taken 30 min after dosing Ca on d 0, 1, 2, 3 and 4 postpartum.

${ }^{2} \mathrm{CaS}=$ effect of Ca supplementation (control vs. CaS1+ CaS4); Dur = effect of duration of CaS (CaS1 vs. CaS4); Par = effect of parity (primiparous vs. multiparous); CaS $\times$ Par $=$ effect of the interaction between CaS and Par; Dur $\times$ Par $=$ effect of the interaction between Dur and Par. ${ }^{3}$ Partial pressure of $\mathrm{CO}_{2}$. 
$2.11 \pm 0.01 \mathrm{mM}$ ). Pretreatment tCa concentrations in serum did not differ among treatments and averaged 2.12, 2.13, and $2.17 \pm 0.02 \mathrm{mM}$ for control, CaS1, and CaS4, respectively. Nevertheless, at $0.5 \mathrm{~h}$ after the first oral administration of $86 \mathrm{~g}$ of $\mathrm{Ca}$ on d 0 , supplemented cows increased $0.26 \pm 0.01 \mathrm{mM}$ of tCa in serum compared with $-0.01 \pm 0.01 \mathrm{~m} M$ change in controls $(P$ $<0.01)$. The increase in tCa was greater $(P<0.01)$ in primiparous cows $(0.34 \pm 0.01 \mathrm{~m} M)$ compared with multiparous cows $(0.17 \pm 0.01 \mathrm{~m} M)$ after receiving $86 \mathrm{~g}$ of oral Ca. During the first 10 DIM, concentration of tCa in serum was greater $(P<0.01)$ for cows supplemented with $\mathrm{Ca}$ compared with controls $(2.21,2.26$, and 2.31 $\pm 0.01 \mathrm{~m} M$ for control, CaS1, and CaS4, respectively). Extending the duration of Ca supplementation with CaS4 compared with CaS1 increased $(P<0.01)$ serum tCa after experiment $\mathrm{d} 1$ within primiparous cows, but not multiparous cows (Figures $4 \mathrm{C}$ and $4 \mathrm{D}$ ).
The model for analysis of incidence of SCH is presented in Table 3, and the same approach was used for all other binary data. On d 0 and before the first oral treatment, the percentage of cows with $\mathrm{SCH}$ was 48.0, 49.3, and $36.5 \%$ for control, CaS1, and CaS4, respectively. In spite of the increase in concentrations of $\mathrm{Ca}$ in $\mathrm{CaS1}$ and $\mathrm{CaS4}$, the incidence of $\mathrm{SCH}$ after treatments and in the first $4 \mathrm{~d}$ in the experiment was $55.9 \%(248 / 444)$. Control cows had greater $(P<0.01)$ incidence of SCH compared with cows supplemented with $\mathrm{Ca}$, and the benefit was further increased by extending $\mathrm{Ca}$ supplementation with $\mathrm{CaS} 4$ (control = 69.3, $\mathrm{CaS} 1=57.5, \mathrm{CaS} 4=34.2 \%)$. In addition, a tendency for an interaction $(P=0.08)$ between duration of Ca supplementation and risk of metritis was observed because among LRM cows, CaS4 reduced the incidence of SCH compared with CaS1, but among HRM cows the incidence of $\mathrm{SCH}$ did not differ between $\mathrm{CaS} 4$ and

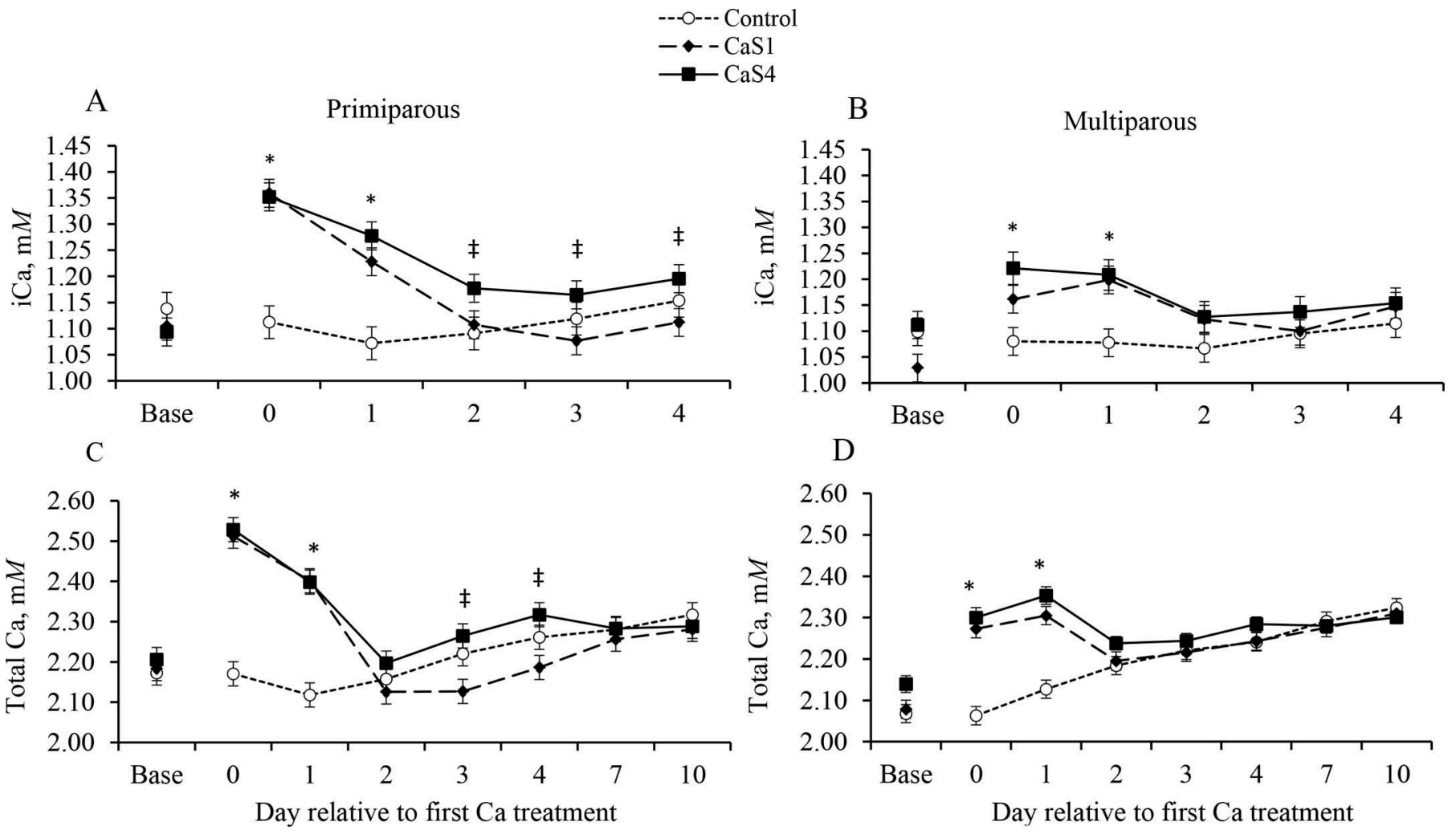

Figure 4. Blood ionized $\mathrm{Ca}$ and serum total $\mathrm{Ca}$ in primiparous (A and $\mathrm{C}$ ) and multiparous cows (B and D) in the first $10 \mathrm{~d}$ relative to the first treatment for control, CaS1, and CaS4 treatments in experiment 2. Blood was sampled and analyzed for iCa in a subset of 10 randomly selected blocks representing 60 Holstein cows, 10 primiparous and 10 multiparous cows per treatment in experiment 2 . Total Ca was analyzed in serum sampled from all 444 cows in experiment 2. Control received no supplemental oral Ca. CaS1 received $86 \mathrm{~g}$ of oral Ca at 0 and $1 \mathrm{~d}$ postpartum. CaS4 received $86 \mathrm{~g}$ of oral Ca at 0 and $1 \mathrm{~d}$ postpartum, and $43 \mathrm{~g}$ at 2, 3, and $4 \mathrm{~d}$ postpartum. Base represents the concentration immediately before treatment on d 0 and used as covariate during statistical analysis. Panels A and B: effect of Ca supplementation [control vs. (CaS1 + CaS4), $P<0.01$, duration of supplementation (CaS1 vs. CaS4, $P<0.01)$, parity $(P<0.01)$, day $(P<0.01)$, and interaction between treatment and day $(P<0.01)$. Panels $\mathrm{C}$ and $\mathrm{D}=$ effect of Ca supplementation $(P<0.01)$, duration Ca supplementation $(P<0.01)$, parity $(P=0.11)$, day $(P<0.01)$, and interaction between treatment and day $(P<0.01)$. ${ }^{*}$ Within day, control vs. $(\mathrm{CaS} 1+\mathrm{CaS} 4)$ differ $(P<0.01)$. $\ddagger$ Within day, CaS1 and CaS4 differ $(P<0.05)$. Error bars depict SEM. The pooled SEM for iCa in primiparous and multiparous, and for total $\mathrm{Ca}$ in primiparous and multiparous were, respectively, 0.031, 0.029, 0.024, and 0.019. 
Table 3. Results of the model to analyze the incidence of subclinical hypocalcemia ( $\mathrm{SCH}$ ) in dairy cows based on plasma total Ca $<2.125 \mathrm{~m} M$ in the first $4 \mathrm{~d}$ in the experiment ${ }^{1}$

\begin{tabular}{|c|c|c|c|c|c|c|c|c|}
\hline Item & $\underset{\%}{\mathrm{SCH}}$ & $\beta$ & $\mathrm{SE} \beta$ & $\begin{array}{c}\text { Adjusted } \\
\text { RR }\end{array}$ & SE RR & $95 \% \mathrm{CI}$ & $x^{2}$ & $P$-value \\
\hline \multicolumn{9}{|l|}{ Ca supplementation } \\
\hline \multicolumn{9}{|l|}{ Ca duration } \\
\hline CaS1 & 57.5 & 0.521 & 0.147 & 1.68 & 0.25 & 1.26 to 2.25 & 12.5 & $<0.01$ \\
\hline CaS4 & 34.2 & - & - & Referent & - & - & - & - \\
\hline Primiparous & 47.6 & - & - & Referent & - & - & - & - \\
\hline \multicolumn{9}{|l|}{ Risk group $^{2}$} \\
\hline HRM & 62.0 & 0.374 & 0.106 & 1.45 & 0.15 & 1.18 to 1.79 & 12.5 & $<0.01$ \\
\hline LRM & 42.7 & - & - & Referent & - & - & - & - \\
\hline \multicolumn{9}{|l|}{ Ca supplementation by parity ${ }^{3}$} \\
\hline CaS1-M + CaS4-M + Control-P & 55.7 & -0.199 & 0.378 & 0.82 & 0.31 & 0.39 to 1.72 & 0.28 & 0.60 \\
\hline CaS1-P + CaS4-P + Control-M & 61.4 & - & - & Referent & - & - & - & - \\
\hline \multicolumn{9}{|l|}{ Ca supplementation by risk } \\
\hline CaS1-LRM + CaS4-LRM + Control-HRM & 46.0 & - & - & Referent & - & - & - & - \\
\hline \multicolumn{9}{|l|}{ Ca duration by risk } \\
\hline CaS1-HRM + CaS4-LRM & 43.2 & -0.510 & 0.295 & 0.60 & 0.18 & 0.34 to 1.07 & 3.00 & 0.08 \\
\hline CaS1-LRM + CaS4-HRM & 50.5 & - & - & Referent & - & - & - & - \\
\hline
\end{tabular}

${ }^{1} \mathrm{RR}=$ relative risk. Control $=$ no Ca supplementation postpartum; CaS1 $=$ cows received $86 \mathrm{~g}$ of Ca per day on d 0 and 1 postpartum; CaS4 $=$ cows received $86 \mathrm{~g}$ of Ca per day on $\mathrm{d} 0$ and 1 postpartum, and then $43 \mathrm{~g}$ of Ca per day on $\mathrm{d} 2,3$, and 4 postpartum.

${ }^{2}$ Low risk of metritis $(\mathrm{LRM})=$ cows that calved with no dystocia, singleton live calf, no retained placenta, and no vaginal laceration. High risk of metritis $(\mathrm{HRM})=$ cows that had at least one of the following: dystocia, twins, stillbirth, retained placenta, or vaginal laceration.

${ }^{3} \mathrm{M}=$ multiparous; $\mathrm{P}=$ primiparous.

CaS1 (Tables 3 and 4). The daily prevalence of SCH in the first 10 DIM was reduced by Ca supplementation $(P<0.01)$ and by duration of supplementation $(P=$ 0.05 ; Figure 5$)$. Oral Ca reduced $(P<0.01)$ the prevalence of $\mathrm{SCH}$ in primiparous and multiparous cows on $\mathrm{d}$ 0 and 1 postpartum. After 1 DIM, treatments no longer affected the prevalence of $\mathrm{SCH}$ in multiparous cows; however, the extended treatment with CaS4 reduced $\mathrm{SCH}$ in primiparous cows up to 4 DIM, whereas stopping oral Ca administration on 1 DIM in CaS1 resulted in a rebound and increased prevalence of SCH from d 2 to 4 postpartum compared with CaS4.

\section{Blood Concentrations of $\mathrm{Na}$ and $\mathrm{K}$ and Serum Concentrations of $\mathrm{Mg}$}

Blood concentrations of $\mathrm{Na}$ were not affected by oral Ca supplementation or duration of Ca supplementation, and averaged 142.1, 142.7, and $142.2 \pm 0.2 \mathrm{mM}$ for control, CaS1, and CaS4, respectively. Similarly, supplemental $\mathrm{Ca}$ or duration of $\mathrm{Ca}$ supplementation did not affect concentrations of $\mathrm{K}$ in cows $(4.14,4.21$, and $4.21 \pm 0.04 \mathrm{mM}$, for control, CaS1, and CaS4, respectively).
Serum Mg concentrations measured in all 444 cows were similar among treatments before $\mathrm{Ca}$ dosing and at $0.5 \mathrm{~h}$ after the first $\mathrm{Ca}$ supplementation. An interaction between $\mathrm{Ca}$ supplementation and parity $(P<$ $0.01)$ was observed because oral Ca reduced $(P<0.05)$ $\mathrm{Mg}$ concentrations in primiparous cows $(0.95,0.91$, and $0.93 \pm 0.01 \mathrm{~m} M$ for control, CaS1, and CaS4, respectively), whereas it increased in multiparous cows (0.91, 0.91, and $0.94 \pm 0.01 \mathrm{~m} M$ for control, CaS1, and CaS4 respectively; Figure 6). The effect of level of Ca supplementation on $\mathrm{Mg}$ concentrations in multiparous cows was only observed starting on d 3 postpartum. In addition, the duration of supplementation affected $\mathrm{Mg}$ concentrations. Cows in the CaS1 had less $(P<0.01)$ $\mathrm{Mg}$ concentrations compared with CaS4 cows (0.93, 0.91 , and $0.94 \pm 0.01 \mathrm{mM}$ for control, CaS1, and CaS4, respectively).

\section{Serum Concentrations of Glucose, Fatty Acids, and BHB}

Supplementation with Ca or duration of supplementation did not influence concentrations of glucose in serum in the first 10 DIM, which averaged 3.05, 3.11, 
and $3.16 \pm 0.04 \mathrm{mM}$ for control, CaS1, and CaS4, respectively (Figure 7A). Calcium supplementation tended $(P=0.06)$ to increase concentrations of fatty acids in serum, which averaged $0.56,0.63$, and $0.60 \pm 0.02$ $\mathrm{m} M$, for control, CaS1, and CaS4, respectively, during the first 10 DIM (Figure 7B). Concentrations of BHB increased in the first 10 DIM in all treatments (Figure $8)$. A tendency $(P=0.07)$ for interaction between $\mathrm{Ca}$ supplementation and risk of metritis was observed for serum BHB because oral Ca increased BHB in LRM, but caused a small decrease in HRM.

\section{Fever and Uterine Diseases}

Three cows left the herd before 10 DIM and were excluded from the analysis of metritis and puerperal metritis. An additional 14 cows were not included in the analysis of clinical endometritis because they either left the herd by 33 DIM (10 cows) or had no informa- tion collected for vaginal discharge at $32 \pm 3$ DIM (n $=4$ ).

Two hundred of the 444 cows in the study had at least $1 \mathrm{~d}$ of rectal temperature $\geq 39.5^{\circ} \mathrm{C}$ in the first 10 DIM. Treatment did not affect the incidence of fever, which was greater $(P<0.01)$ for HRM than LRM and for primiparous than multiparous cows (Tables 4 and 5). Metritis affected $37.9 \%(167 / 441)$ of the experimental cows. Contrary to the initial hypothesis, cows supplemented with $\mathrm{Ca}$ had $(P=0.05)$ increased incidence of metritis compared with control cows, but no difference was observed between CaS1 and CaS4 (Table 6). Primiparous cows were more likely $(P<0.001)$ to have metritis than multiparous cows (Table 4 ), and those at HRM had greater $(P<0.001)$ incidence of metritis than LRM cows (Table 5). An interaction $(P<0.001)$ was detected between parity and risk group because the increment in metritis incidence from the LRM to the HRM group was greater in multiparous than primipa-

Table 4. Incidence of diseases in the early postpartum period and removal from the herd according to risk and treatment in experiment $2^{1}$

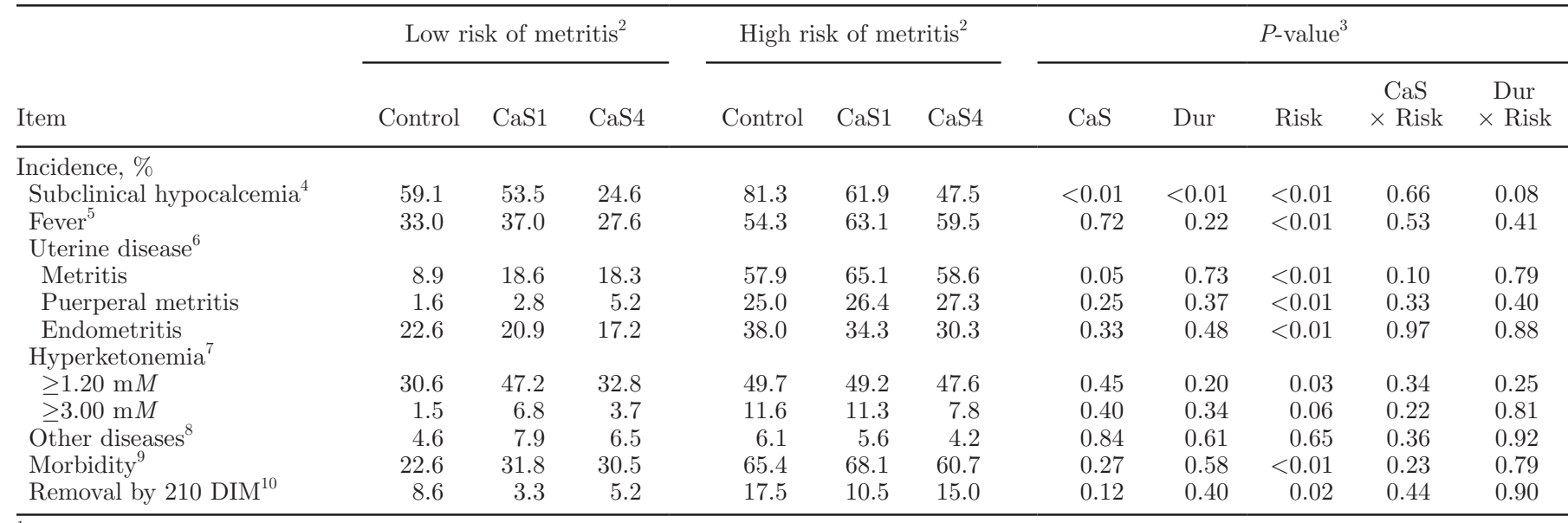

${ }^{1}$ Control = no Ca supplementation postpartum; CaS1 = cows received $86 \mathrm{~g}$ of Ca per day on d 0 and 1 postpartum; CaS4 = cows received $86 \mathrm{~g}$ of Ca per day on $\mathrm{d} 0$ and 1 postpartum, and then $43 \mathrm{~g}$ of Ca per day on $\mathrm{d} 2,3$, and 4 postpartum.

${ }^{2}$ Low risk of metritis = cows that calved with no dystocia, singleton live calf, no retained placenta, and no vaginal laceration. High risk of metritis $(\mathrm{HRM})=$ cows that had at least one of the following: dystocia, twins, stillbirth, retained placenta, or vaginal laceration.

${ }^{3} \mathrm{CaS}=$ effect of Ca supplementation (control vs. CaS1+ CaS4); Dur = effect of duration of CaS (CaS1 vs. CaS4); Risk = effect of risk (low vs. high risk of metritis); CaS $\times$ Risk $=$ effect of the interaction between CaS and Risk; Dur $\times$ Risk $=$ effect of the interaction between Dur and Risk.

${ }^{4}$ Total Ca concentrations $<2.125 \mathrm{~m} M$ in at least $1 \mathrm{~d}$ within the first $3 \mathrm{~d}$ postpartum. It does not include the measurement taken on $\mathrm{d} 0$ before treatment administration.

${ }^{5}$ Rectal temperature $\geq 39.5^{\circ} \mathrm{C}$ in the first 10 DIM.

${ }^{6}$ Metritis: = watery, fetid uterine discharge, regardless of fever; puerperal metritis: metritis concurrent with fever; endometritis: vaginal discharge containing at least $10 \%$ white or off-white purulent material evaluated at $32 \pm 3 \mathrm{~d}$ postpartum.

${ }^{7}$ Two hundred ninety-four cows sampled for blood on d $1,2,3,4,7$, and 10 postpartum. BHB concentrations $>1.20 \mathrm{~m} M$ in at least one of the blood samples was considered hyperketonemia; BHB concentrations $\geq 3.00 \mathrm{~m} M$ in at least one of the blood samples was considered clinical ketosis.

${ }^{8}$ Incidence of one or more clinical diseases other than uterine disease and ketosis within the first 30 DIM (includes mastitis, digestive problems, respiratory disease, and locomotion disorders).

${ }^{9}$ Incidence of any clinical disease within the first $30 \mathrm{~d}$ postpartum (metritis, ketosis, mastitis, digestive problems, respiratory disease, and locomotion disorders).

${ }^{10}$ Removal from the herd by either death or culling by $210 \mathrm{~d}$ postpartum. 
- Control
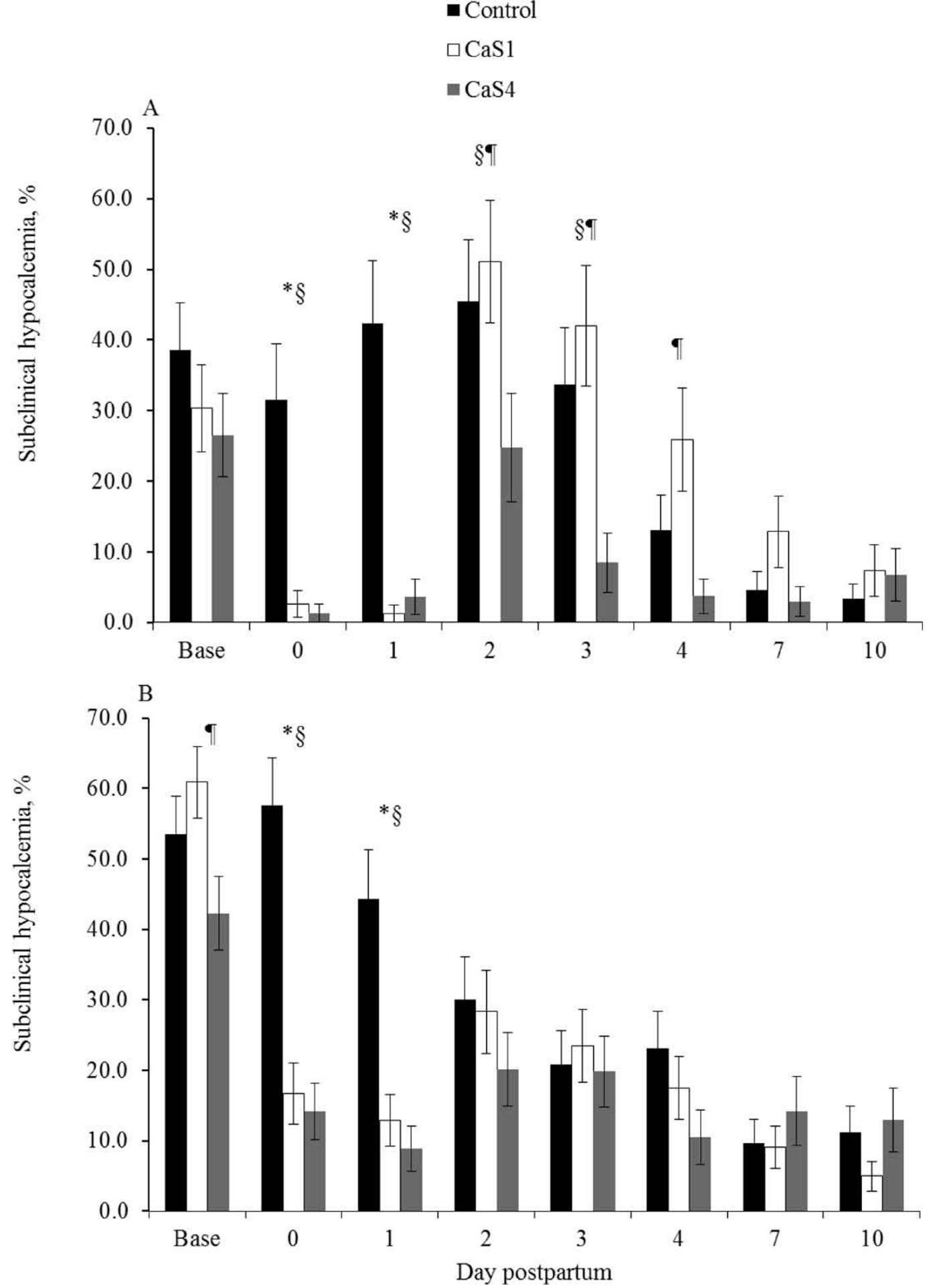

Figure 5. Daily prevalence of subclinical hypocalcemia [total Ca (tCa) $<2.125 \mathrm{mM}$ in primiparous (panel A) and multiparous (panel B) Holstein cows in the first $10 \mathrm{~d}$ relative to the first treatment for control, CaS1, and CaS4 treatments in experiment 2. Blood was sampled and analyzed for tCa in all 444 cows in experiment 2. Control received no supplemental oral Ca. CaS1 received $86 \mathrm{~g}$ of oral Ca at 0 and $1 \mathrm{~d}$ postpartum. CaS4 received $86 \mathrm{~g}$ of oral Ca at 0 and $1 \mathrm{~d}$ postpartum, and $43 \mathrm{~g}$ at 2, 3, and $4 \mathrm{~d}$ postpartum. Base represents the prevalence of subclinical hypocalcemia immediately before treatment on d 0 and it was used as a covariate during statistical analysis. Effect of Ca supplementation [control vs. (CaS1 + CaS4), $P<0.01$, duration of supplementation (CaS1 vs. CaS4, $P=0.05)$, parity $(P<0.01)$, day $(P<0.01)$, and interactions between treatment and day $(P<0.01)$, Ca supplementation and parity $(P=0.47)$, and duration of supplementation and parity $(P=0.06)$. Within day, symbols denote a difference $(P<0.05)$ among treatments after Tukey protection for multiple comparisons $\left({ }^{*}\right.$ control vs. CaS1; $\S$ control vs. CaS4; $\uparrow \mathrm{CaS} 1$ vs. CaS4). Error bars depict SEM. The pooled SEM for primiparous and multiparous were 5.1 and 4.7, respectively. 

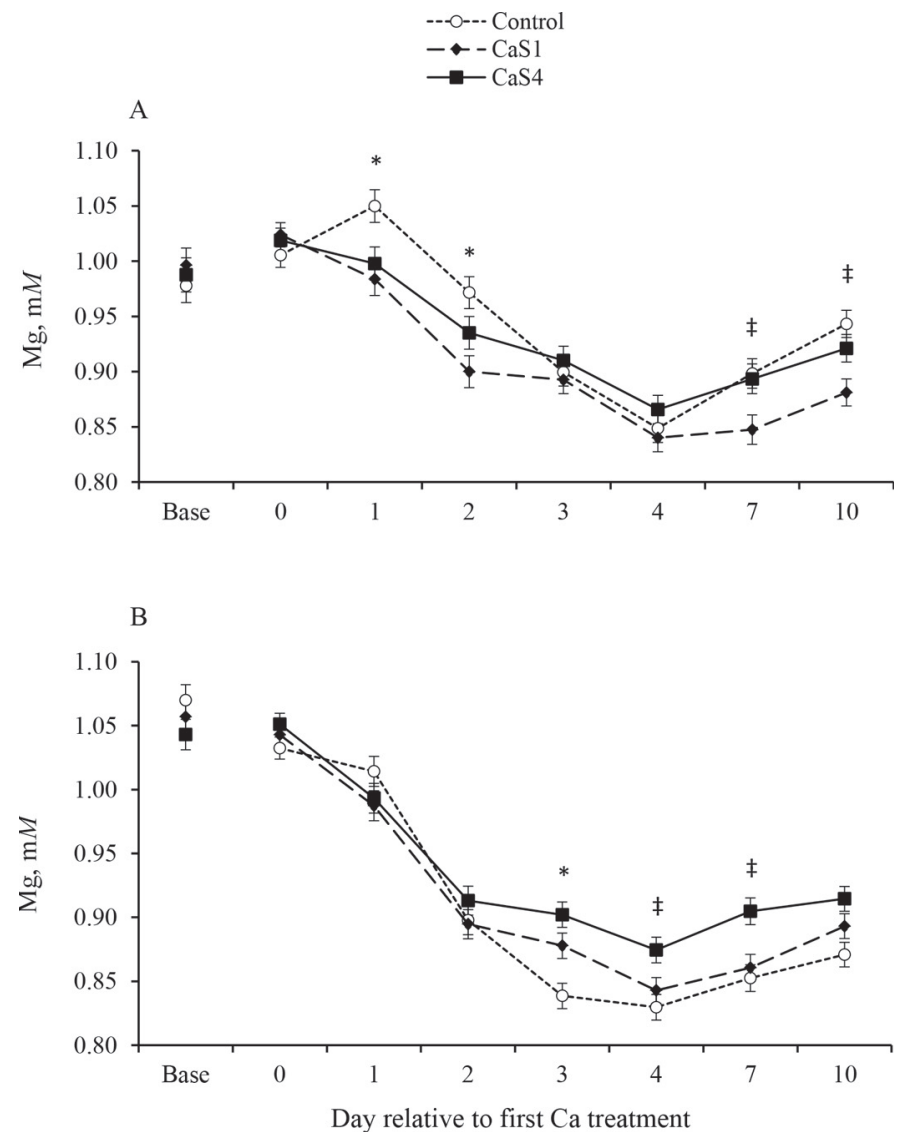

Figure 6. Serum $\mathrm{Mg}$ in primiparous (A) and multiparous cows (B) during the first $10 \mathrm{~d}$ relative to first $\mathrm{Ca}$ treatment for control, CaS1, and CaS4 treatments. Sera were analyzed in all 444 Holstein cows in experiment 2. Control received no supplemental oral Ca. CaS1 received $86 \mathrm{~g}$ of oral Ca at 0 and $1 \mathrm{~d}$ postpartum. CaS4 received $86 \mathrm{~g}$ of oral Ca at 0 and $1 \mathrm{~d}$ postpartum, and $43 \mathrm{~g}$ at 2,3 , and $4 \mathrm{~d}$ postpartum. Base represents the concentration immediately before treatment on $\mathrm{d}$ 0 and it was used as a covariate during statistical analysis. Effect of Ca supplementation [control vs. $(\mathrm{CaS} 1+\mathrm{CaS} 4), P=0.81$, duration of supplementation (CaS1 vs. CaS4, $P<0.01)$, parity $(P<0.06)$, day $(P<0.01)$, and interaction between treatment and day $(P<0.01)$. *Within day, control and $(\mathrm{CaS} 1+\mathrm{CaS} 4)$ differ $(P<0.01)$. $\neq$ Within day, CaS1 and CaS4 differ $(P<0.05)$. Error bars depict SEM. The pooled SEM for $\mathrm{Mg}$ in primiparous and multiparous cows were 0.013 and 0.010 , respectively.

rous cows (multiparous-LRM $=6.9$, multiparous-HRM $=52.5$, primiparous-LRM $=30.2$, primiparous-HRM $=$ $69.7 \%$ ). Interestingly, the negative effects of Ca supplementation were more pronounced (interaction treatment by parity by risk group; $P<0.05)$ in primiparous cows at LRM because in those cows Ca supplementation doubled the incidence of metritis compared with their nonsupplemented counterparts $($ control $=17.9$, $\mathrm{CaS} 1=35.7, \mathrm{CaS} 4=42.9 \%$ ). The incidence of $\mathrm{pu}-$ erperal metritis was $15.6 \%(69 / 441)$, and it was not affected by treatments (Table 4 ). Endometritis affected $27.5 \%$ of the experimental cows $(117 / 426)$, and the prevalence was not influenced by treatments (Table 4 ).
As anticipated, risk group at calving greatly increased $(P<0.01)$ the risk of all uterine diseases evaluated and that of fever (Table 4). Furthermore, primiparous cows were more likely $(P<0.01)$ to be diagnosed with metritis, puerperal metritis, and fever than multiparous cows (Table 5).

Hyperketonemia. Hyperketonemia was diagnosed in $46.6 \%(137 / 294)$ of the cows from 1 to 10 DIM. Neither Ca supplementation nor duration of supplementation affected the incidence of hyperketonemia (Table 4). Cows at HRM and primiparous cows had greater $(P<0.01)$ incidence of hyperketonemia than LRM and multiparous cows, respectively (Tables 4 and 5).
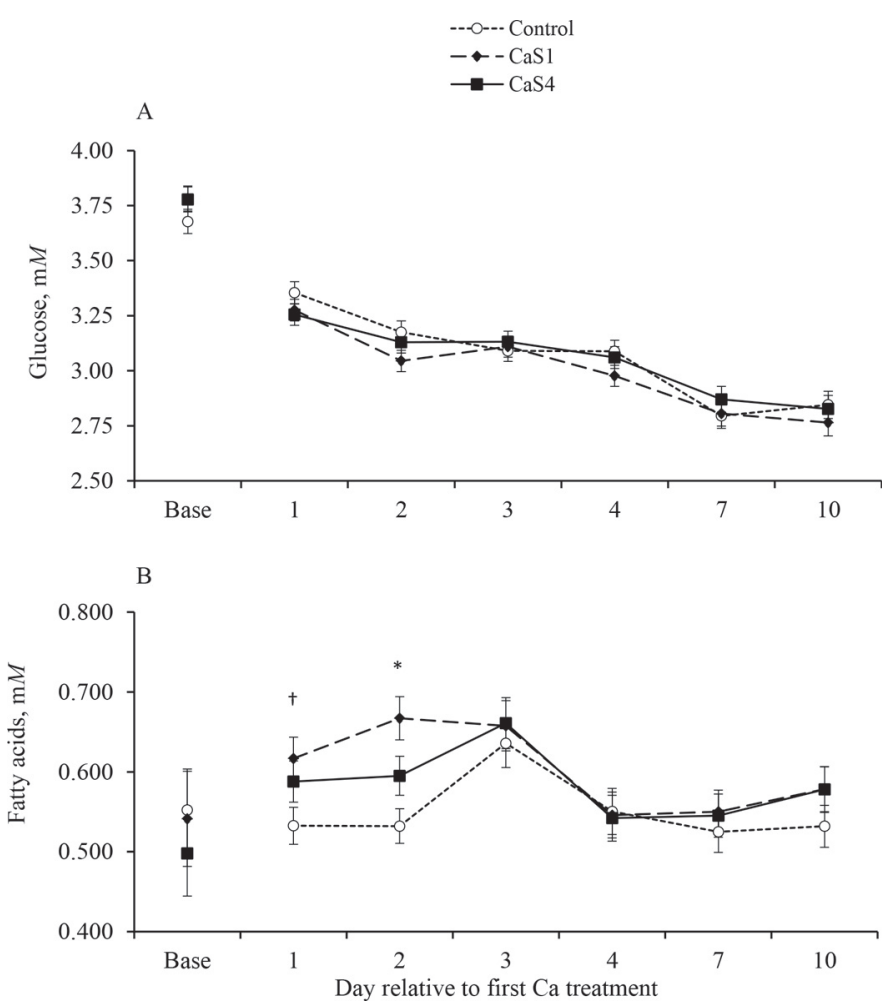

Figure 7. Concentrations of glucose (A) and nonesterified fatty acids (B) in serum during the first $10 \mathrm{~d}$ relative to first Ca treatment for control, CaS1, and CaS4 treatments in experiment 2. Sera were analyzed in a subset of 50 randomly selected blocks representing 294 Holstein cows in experiment 2. Control cows received no supplemental oral Ca. CaS1 cows received $86 \mathrm{~g}$ of oral Ca on $\mathrm{d} 0$ and $1 \mathrm{~d}$ postpartum. CaS4 cows received $86 \mathrm{~g}$ of oral $\mathrm{Ca}$ on $\mathrm{d} 0$ and $1 \mathrm{~d}$ postpartum, and $43 \mathrm{~g}$ on $\mathrm{d} 2,3$, and 4 postpartum. Base represents the concentration immediately before treatment on d 0 and it was used as covariate during statistical analysis. Panel A: effect of Ca supplementation [control vs. $(\mathrm{CaS} 1+\mathrm{CaS} 4) ; P=0.46]$, duration of supplementation (CaS1 vs. CaS4; $P=0.39)$, risk $(P=0.03)$, parity $(P<0.01)$, day $(P<0.01)$, and interaction between treatment and day $(P=0.15)$. Panel B: effect of Ca supplementation $(P=0.06)$, duration of supplementation $(P=0.41)$, risk $(P=0.52)$, parity $(P<0.01)$, day $(P<0.01)$, and interaction between treatment and day $(P=0.08)$. ${ }^{*}$ Within day, treatments differ $(P<0.05)$. $\dagger$ Within day, control differs from CaS1 $(P<$ 0.05). Error bars depict the SEM. The pooled SEM for glucose and nonesterified fatty acids were 0.05 and 0.03 , respectively. 

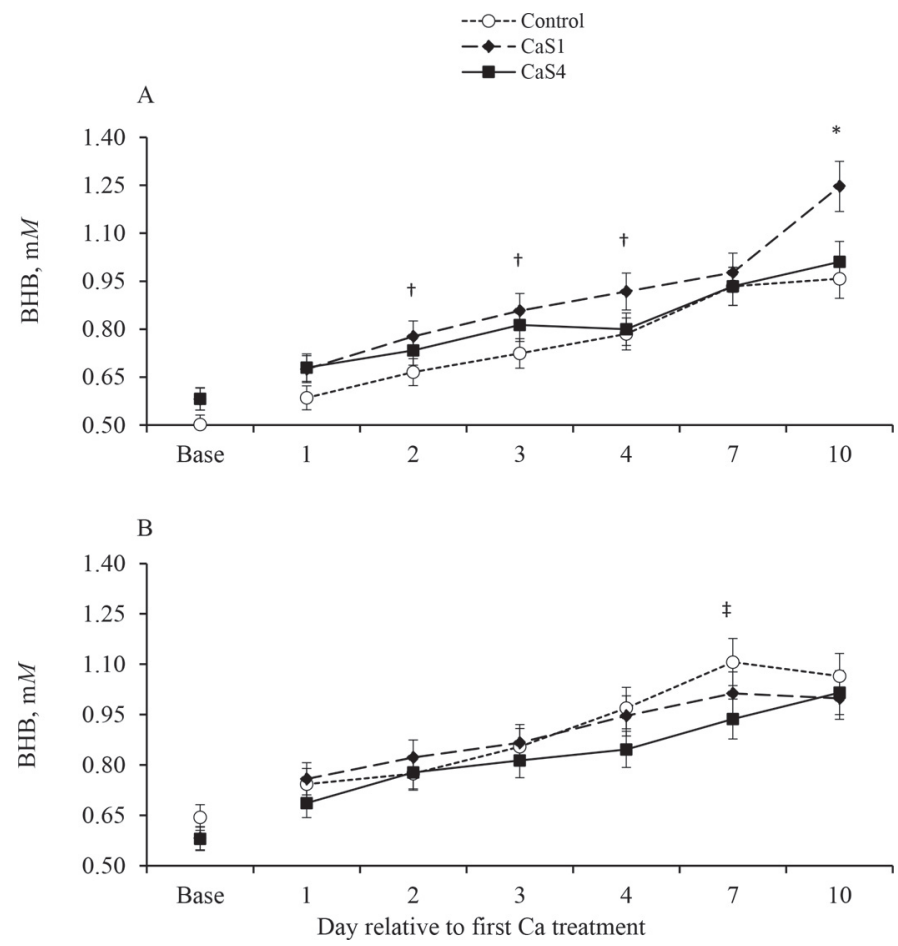

Figure 8. Concentrations of BHB in serum during the first $10 \mathrm{~d}$ relative to first Ca treatment in cows of low (A) or high risk of metritis (B) in experiment 2. Sera were analyzed in a subset of 50 randomly selected blocks representing 294 Holstein cows in experiment 2. Control cows received no supplemental oral Ca. CaS1 cows received $86 \mathrm{~g}$ of oral $\mathrm{Ca}$ on $\mathrm{d} 0$ and 1 postpartum. CaS4 cows received $86 \mathrm{~g}$ of oral Ca on $\mathrm{d}$ 0 and $1 \mathrm{~d}$ postpartum, and $43 \mathrm{~g}$ on $\mathrm{d} 2,3$, and $4 \mathrm{~d}$ postpartum. LRM $=$ low risk of metritis; HRM = high risk of metritis. Base represents the concentration immediately before treatment on $\mathrm{d} 0$ and it was used as covariate during statistical analysis. Effect of Ca supplementation [control vs. (CaS1+CaS4); $P=0.43$ ], duration of supplementation (CaS1 vs. CaS4; $P=0.13)$, risk $(P=0.10)$, interaction between Ca supplementation and risk $(P=0.07)$, and interaction between duration and risk $(P=0.85)$. $†$ Within day, CaS1 differ from control $(P<$ 0.05). *Within hour, CaS1 differ from control and CaS4 $(P<0.05)$. $\ddagger$ Within day, CaS4 differ from control $(P<0.05)$. Error bars depict SEM. The pooled SEM for BHB in cows of low and high risk of metritis were 0.05 and 0.05 , respectively.

Clinical Ketosis and Other Postpartum Diseases. Clinical ketosis based on serum BHB $\geq 3.0$ $\mathrm{m} M$ affected $9.5 \%$ (28/294) of the experimental cows. Treatments did not influence the incidence of clinical ketosis, which affected $9.2,12.2$, and $7.1 \%$ of the control, CaS1, and CaS4 cows, respectively (Table 4). Similar to hyperketonemia, HRM tended to have $(P$ $=0.06)$ and primiparous cows had greater $(P<0.01)$ incidence of clinical ketosis than LRM and multiparous cows, respectively (Tables 4 and 5).

A total of $7.2 \%(32 / 443)$ of the cows were diagnosed with other early postpartum diseases in the first 30 DIM, including mastitis $(2.7 \% ; 12 / 443)$, lameness $(2.5 \% ; 11 / 443)$, digestive problems $(1.6 \% ; 7 / 443)$, or clinical hypocalcemia $(0.45 \% ; 2 / 443)$. An interaction
$(P=0.03)$ between $\mathrm{Ca}$ supplementation and parity was observed for other diseases because in primiparous cows, supplementation increased the incidence of these diseases compared with controls, whereas for multiparous cows, Ca supplementation reduced incidence of these diseases compared with controls (Table 5).

Morbidity. Morbidity, defined as a cow with at least one clinical disease in the first 30 DIM, affected $46.0 \%$ (204/444) of the experimental cows, and the mean number of clinical disease events per cow was 0.51 . An interaction $(P=0.02)$ between supplemental $\mathrm{Ca}$ and parity was observed for morbidity (Table 5). Oral Ca increased morbidity within primiparous cows, but had no effect on multiparous cows. Morbidity was greater $(P<0.01)$ for HRM than LRM and for primiparous than multiparous cows (Tables 4 and 5).

\section{Removal from the Herd}

By 210 d postpartum, 12.8\% (57/444) of the experimental cows had been removed from the herd. Two cows were euthanized on the farm and the remaining 55 were culled. Supplementation with Ca did not influence the risk of removal from the herd, affecting 16.2, 10.1, and $12.4 \%$ of control, CaS1, and CaS4 cows, respectively (Table 4$)$. As expected, cows at HRM had greater $(P=$ 0.02 ) risk of leaving the herd compared with LRM cows $(\mathrm{LRM}=9.5$ vs. $\mathrm{HRM}=16.2 \%)$. Multiparous cows had greater $(P<0.001)$ risk of leaving the herd compared with primiparous cows (primiparous $=6.6$ vs. multiparous $=16.7 \%$; Table 5). Because removal from the herd was not affected by treatment, the number of days in the experiment did not differ among treatments and averaged 182, 176, and $191 \pm 4 \mathrm{~d}$ for control, CaS1, and CaS4.

\section{DISCUSSION}

The main objectives of the present experiments were to characterize concentrations of $\mathrm{Ca}$ in blood after oral supplementation with Ca salts and to evaluate strategies for oral Ca supplementation to minimize $\mathrm{SCH}$ and the risk of uterine disease in cows of low or high risk of developing metritis. Experiment 1 was designed to evaluate the extent to which oral Ca supplementation with 43 or $86 \mathrm{~g}$ as a single dose alters blood mineral composition and acid-base status. The results showed that supplementation increases blood concentrations of total and iCa in a dose-dependent manner, and that 86 $\mathrm{g}$ was capable of elevating blood Ca concentrations between 4 to $8 \mathrm{~h}$. Experiment 2 was designed based on the hypothesis that supplementing oral $\mathrm{Ca}$ would reduce the risk of SCH and improve postpartum health. Contrary to our hypothesis, the supplementation strategies 
selected did not reduce the risk of uterine diseases. In fact, in spite of reducing the incidence and prevalence of $\mathrm{SCH}$, supplemental $\mathrm{Ca}$ increased the incidence of metritis, particularly in LRM primiparous cows. Nevertheless, important interactions were detected between Ca supplementation and parity or risk of metritis, suggesting that potential effects of Ca depend on the population of cows treated.

The same product used to supplement Ca has been used by others as a 2-bolus regimen administered 12 $\mathrm{h}$ apart, with the first dosed in the first hours after calving (Oetzel and Miller, 2012). The rationale for the treatments chosen for experiment 2, which deviated from the dose regimen used by Oetzel and Miller (2012), was based on the findings that $43 \mathrm{~g}$ of $\mathrm{Ca}$ as $\mathrm{CaCl}_{2}$ and $\mathrm{CaSO}_{4}$ had limited ability to increase blood $\mathrm{iCa}$ and $\mathrm{tCa}$ and the fact that the work by Oetzel and Miller (2012) showed no increments in blood Ca or reduction in risk of metritis with a single bolus administered twice at a 12-h interval. We had previously conducted a pilot experiment with multiparous Holstein cows receiving $0,43,86$, or $129 \mathrm{~g}$ of oral Ca as a bolus of chloride and sulfate salts and showed that at least $86 \mathrm{~g}$ was required to increase blood Ca concentrations (data not shown). Experiment 1 replicated those findings and showed that $86 \mathrm{~g}$ of oral $\mathrm{Ca}$ was needed to increase blood iCa between 4 to $8 \mathrm{~h}$ after administration to primiparous and multiparous cows. Because of the concentration of $\mathrm{Ca}$ in the bolus, only multiples of $43 \mathrm{~g}$ could be implemented.

Oral dosing of Ca likely results in Ca absorption by mechanisms of passive diffusion. It has been shown that iCa concentrations greater than $6 \mathrm{mM}$ in the lumen of the gastrointestinal tract are needed to induce a chemical downgradient that results in passive transport (Höller et al., 1988). The gradient induces diffusion from the lumen through the tight junctions toward the extracellular space where iCa concentrations are about 1.2 to $1.4 \mathrm{mM}$ (Bronner, 1987). We did not measure iCa concentration in the rumen fluid, but Holstein cows in the first few days postpartum have a rumen capacity of approximately $150 \mathrm{~L}$ (Park et al., 2011), with 35 to $40 \%$ of that occupied by liquid. Therefore, a postpartum Holstein cow with 55 to $60 \mathrm{~L}$ of liquid in the rumen

Table 5. Incidence of diseases in the early postpartum period and removal from the herd according to parity and treatment in experiment $2^{1}$

\begin{tabular}{|c|c|c|c|c|c|c|c|c|c|c|c|}
\hline Item & \multicolumn{3}{|c|}{ Primiparous } & \multicolumn{3}{|c|}{ Multiparous } & \multicolumn{5}{|c|}{$P$-value ${ }^{2}$} \\
\hline Subclinical hypocalcemia ${ }^{3}$ & 66.3 & 58.9 & 27.7 & 72.4 & 56.1 & 42.2 & $<0.01$ & $<0.01$ & 0.14 & 0.60 & 0.11 \\
\hline Fever $^{4}$ & 59.8 & 62.3 & 58.3 & 30.0 & 37.5 & 28.2 & 0.72 & 0.22 & $<0.01$ & 0.77 & 0.40 \\
\hline \multicolumn{12}{|l|}{ Uterine disease $^{5}$} \\
\hline \multicolumn{12}{|l|}{ Hyperketonemia $^{6}$} \\
\hline$\geq 1.20 \mathrm{~m} M$ & 53.3 & 66.1 & 56.5 & 28.5 & 35.1 & 27.6 & 0.45 & 0.20 & $<0.01$ & 0.87 & 0.79 \\
\hline$\geq 3.00 \mathrm{~m} M$ & 7.6 & 18.2 & 10.4 & 2.3 & 4.2 & 2.8 & 0.40 & 0.34 & 0.01 & 0.83 & 0.88 \\
\hline Other diseases ${ }^{7}$ & 1.7 & 7.1 & 5.0 & 16.3 & 6.2 & 5.3 & 0.84 & 0.61 & 0.14 & 0.03 & 0.92 \\
\hline Morbidity $^{8}$ & 38.1 & 61.8 & 60.3 & 38.2 & 35.1 & 30.1 & 0.27 & 0.58 & $<0.01$ & 0.02 & 0.70 \\
\hline Removal by 210 DIM $^{9}$ & 7.3 & 2.5 & 5.2 & 20.6 & 13.6 & 14.8 & 0.12 & 0.40 & $<0.01$ & 0.62 & 0.48 \\
\hline
\end{tabular}

${ }^{1}$ Control $=$ no Ca supplementation postpartum; CaS1 $=$ cows received $86 \mathrm{~g}$ of Ca per day on $\mathrm{d} 0$ and 1 postpartum; CaS4 = cows received $86 \mathrm{~g}$ of Ca per day on $\mathrm{d} 0$ and 1 postpartum, and then $43 \mathrm{~g}$ of Ca per day on $\mathrm{d} 2,3$, and 4 postpartum.

${ }^{2} \mathrm{CaS}=$ effect of Ca supplementation (control vs. CaS1+ CaS4); Dur = effect of duration of CaS (CaS1 vs. CaS4); Par = effect of parity (primiparous vs. multiparous); CaS $\times$ Par $=$ effect of the interaction between CaS and Par; Dur $\times$ Par $=$ effect of the interaction between Dur and Par.

${ }^{3}$ Total Ca concentrations $<2.125 \mathrm{~m} M$ in at least $1 \mathrm{~d}$ within the first $3 \mathrm{~d}$ postpartum. It does not include the measurement taken on d 0 before treatment administration.

${ }^{4}$ Rectal temperature $\geq 39.5^{\circ} \mathrm{C}$ in the first $10 \mathrm{DIM}$.

${ }^{5}$ Metritis: watery, fetid uterine discharge, regardless of fever; puerperal metritis: metritis concurrent with fever; endometritis: vaginal discharge containing at least $10 \%$ white or off-white purulent material evaluated at $32 \pm 3 \mathrm{~d}$ postpartum.

${ }^{6}$ Two hundred ninety-four cows sampled for blood on d 1, 2, 3, 4, 7, and 10 postpartum. BHB concentrations $\geq 1.20 \mathrm{~m} M$ in at least one of the blood samples was considered hyperketonemia; BHB concentrations $\geq 3.00 \mathrm{~m} M$ in at least one of the blood samples was considered clinical ketosis.

${ }^{7}$ Incidence of one or more clinical diseases other than uterine disease and ketosis within the first 30 DIM (includes mastitis, digestive problems, respiratory disease, and locomotion disorders).

${ }^{8}$ Incidence of any clinical disease within the first $30 \mathrm{~d}$ postpartum (metritis, ketosis, mastitis, digestive problems, respiratory disease, and locomotion disorders).

${ }^{9}$ Removal from the herd by either death or culling by $210 \mathrm{~d}$ postpartum. 
Table 6. Results of the model used to analyze the incidence of metritis in dairy cows ${ }^{1}$

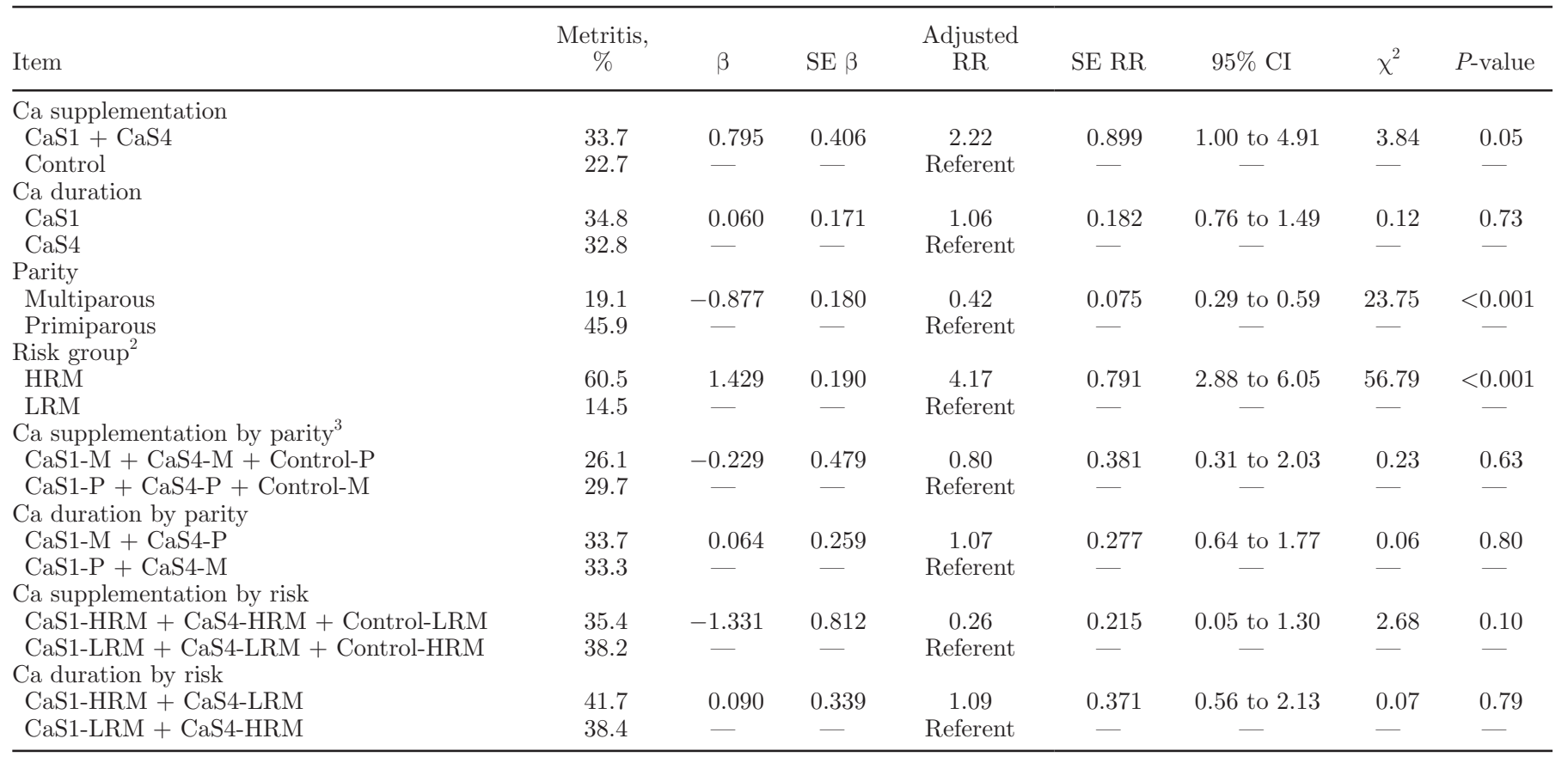

${ }^{1} \mathrm{RR}=$ relative risk. Control $=$ no Ca supplementation postpartum; CaS1 $=$ cows received 86 g of Ca per day on d 0 and 1 postpartum; CaS4 $=$ cows received $86 \mathrm{~g}$ of Ca per day on $\mathrm{d} 0$ and 1 postpartum, and then $43 \mathrm{~g}$ of Ca per day on $\mathrm{d} 2,3$, and 4 postpartum.

${ }^{2}$ Low risk of metritis $(\mathrm{LRM})=$ cows that calved with no dystocia, singleton live calf, no retained placenta, and no vaginal laceration. High risk of metritis $(\mathrm{HRM})=$ cows that had at least one of the following: dystocia, twins, stillbirth, retained placenta, or vaginal laceration.

${ }^{3} \mathrm{M}=$ multiparous; $\mathrm{P}=$ primiparous.

would have Ca concentrations greater than $10 \mathrm{~m} M$ if all $\mathrm{CaCl}_{2}$ and a portion of the $\mathrm{CaSO}_{4}$ in each bolus are solubilized, which is greater than the estimated amount required to cross the epithelium (Höller et al., 1988). Obviously, the Ca concentration in the rumen fluid is unlikely to be homogeneous, ionization is not instantaneous, and concentrations will differ according to location and time after treatment. Also, some of the Ca passes with the liquid and solid phases of the rumen content, and some will complex with UFA forming soaps, but it is more than likely that administration of $86 \mathrm{~g}$ of $\mathrm{Ca}$ as an oral dose resulted in passive diffusion of iCa through the rumen-reticulum.

The increase in blood iCa with dosing $86 \mathrm{~g}$ of oral $\mathrm{Ca}$ was slightly less in experiment 1 than 2 . It is likely that the smaller sample size and the fact that only LRM cows were used in experiment 1 explain the smaller increment in blood iCa than that observed in experiment 2 . Experiment 2 showed that the increase in $\mathrm{iCa}$ concentrations in blood after $86 \mathrm{~g}$ of Ca was only half the magnitude in multiparous compared with primiparous cows. Such differences suggest that multiparous cows either had larger rumen volume with different absorption rate, or simply rapidly incorporated the absorbed Ca into tissues such as milk or bone, or had increased urinary excretion. Active transport of $\mathrm{Ca}$ in the intes- tine is regulated by $1,25(\mathrm{OH})_{2} \mathrm{D}_{3}$ through vitamin $\mathrm{D}$ receptors (Fujita et al., 2008), and aging is associated with decreased number of vitamin $\mathrm{D}$ receptors in the intestine of dairy cattle (Horst et al., 1990), which could reduce $\mathrm{Ca}$ absorption in multiparous cows. Multiparous cows produced $2.5 \mathrm{~kg}$ more colostrum compared with primiparous cows, which would remove an additional $5.5 \mathrm{~g}$ of Ca. Multiparous cows also are expected to have increased DMI compared with primiparous cows, which causes a faster rate of passage of the digestive content through the rumen-reticulum. Multiparous cows also are heavier, with a larger vascular pool, which would dilute some of the absorbed Ca. Collectively, these differences between primiparous and multiparous cows likely explain some of the changes in blood Ca observed according to parity.

Blood $\mathrm{pH}$ did not change with the administration of 2.2 or 4.4 equivalents of strong anions from the combined $\mathrm{Cl}^{-}$and $\mathrm{SO}_{4}{ }^{-2}$ contained in the 43- or 86-g dose, respectively. However, these anions reduced $\mathrm{HCO}_{3}$, base excess, and $\mathrm{PCO}_{2}$ after $\mathrm{Ca}$ supplementation, effects that were observed in primiparous cows during the first 4 DIM. These changes suggest a compensated metabolic acidosis for cows dosed with acidogenic $\mathrm{Ca}$ salts (Constable, 2014). A possible explanation for lack of changes in $\mathrm{pH}$ is that as $\mathrm{H}^{+}$starts accumulating in 
blood, buffering of $\mathrm{H}^{+}$ions with $\mathrm{HCO}_{3}$ results in production of $\mathrm{H}_{2} \mathrm{O}$ and $\mathrm{CO}_{2}$. The resulting accumulation of $\mathrm{CO}_{2}$ is alleviated by increased alveolar ventilation leading to reduction of blood $\mathrm{pCO}_{2}$. In addition, the excretion of large amounts of $\mathrm{H}^{+}$ions in urine has been widely documented with acidogenic salt supplementation (Goff and Horst, 1994; Sampson et al., 2009). Furthermore, the increase in serum tCa observed with supplementation suggests that a portion of the equivalents of strong anions was neutralized by the absorbed $\mathrm{Ca}$, therefore reducing the retention of $\mathrm{H}$ and the consequent drop in blood $\mathrm{pH}$.

The prevalence of SCH before oral Ca was administered was $44.6 \%$. Even after treatments were implemented, the incidence of SCH during the first 3 DIM remained high, affecting $55.9 \%$ of the experimental cows. The incidence of SCH reported herein is greater than values reported by others in which cows also received oral Ca supplementation (40.7\%; Oetzel, 1996). Half of the cows in the present experiment had calving problems, which is associated with reduced serum concentrations of Ca (Martinez et al., 2012). Also, the threshold of tCa $<2.125 \mathrm{~m} M$ to define SCH (Martinez et al., 2012) was greater than the $<2.0 \mathrm{~m} M$ used by others (Oetzel, 1996; Reinhardt et al., 2011). Furthermore, the daily sampling of blood in the current experiment allowed us to estimate incidence of $\mathrm{SCH}$, whereas others have used a single blood sample to evaluate prevalence (Reinhardt et al., 2011). It is clear from Figure 5 that, depending on the day when blood is sampled, the prevalence is variable. Nevertheless, supplemental $\mathrm{Ca}$ reduced the incidence and the prevalence of $\mathrm{SCH}$ and the effects were greater when supplementation was extended with CaS4. The inability of CaS1 to reduce the incidence of SCH was likely caused by cows having serum tCa below the designated threshold after supplementation ended on d 1 postpartum. Indeed, on d 2 postpartum, the prevalence of SCH in control, CaS1, and CaS4 were 37.2, 40.0, and 21.4\%, respectively, and the differences between treatments were more pronounced in primiparous cows. It is important to note that blood was sampled $0.5 \mathrm{~h}$ after $\mathrm{Ca}$ administration, which was when serum tCa had already increased after oral dosing. If samples were taken later, $8 \mathrm{~h}$ after treatment, then it is likely that prevalence and incidence of $\mathrm{SCH}$ would increase and the differences among treatments would be minimized or even nonexistent (Oetzel and Miller, 2012).

Calcium supplementation had unexpected results relative to health outcomes, with increased incidence of metritis, particularly in primiparous cows at LRM. Furthermore, Ca supplementation had opposite effects on certain diseases according to parity and increased morbidity in primiparous cows. It seems that cows that are less likely to suffer from $\mathrm{SCH}$ such as primiparous and LRM cows respond differently to oral Ca supplementation compared with cows that have increased risk of $\mathrm{SCH}$. It is plausible to suggest that supplementing 86 $\mathrm{g}$ of Ca to primiparous cows for the first $2 \mathrm{~d}$ postpartum was rather excessive and, likely, unnecessary. In fact, primiparous cows had a larger increase in blood iCa and serum tCa after receiving $86 \mathrm{~g}$ of oral $\mathrm{Ca}$ on the day of calving compared with multiparous cows. One could speculate that large oscillations in diurnal Ca concentrations and compensatory mechanisms to balance acid-base status with supplementation of acidogenic salts might be less tolerable for cows that are likely better to maintain adequate blood $\mathrm{Ca}$ concentration. Although the prevalence of $\mathrm{SCH}$ in primiparous cows has been estimated at 25\% (Reinhardt et al., 2011), it seems that reversing the transient decline in blood $\mathrm{Ca}$ in the first days after calving with large doses of oral $\mathrm{Ca}$ is rather detrimental to primiparous cows. From the current data, it remains unknown if the fluctuations in blood $\mathrm{Ca}$ or the compensated metabolic acidosis might have had detrimental effects on primiparous cows.

Supplementation with $\mathrm{Ca}$ in large quantities might interfere with absorption of $\mathrm{Zn}$ and $\mathrm{Mg}$, and increase renal Mg excretion (Hines et al., 1986; Khorasani et al., 1997; Wood and Zheng, 1997). Activation of the Ca sensing receptors by the increase in $\mathrm{iCa}$ in the thick ascending limb of the Henle loop and convoluted tubules inhibits the $\mathrm{Na}-\mathrm{K}-\mathrm{Cl}$ cotransporter, which is important for paracellular reabsorption of $\mathrm{Ca}$ and $\mathrm{Mg}$ (Dai et al., 2001). Therefore, the transient hypercalcemia induced by administration of oral Ca likely caused an increased urinary excretion of $\mathrm{Mg}$, which explains the decrease in blood concentrations of $\mathrm{Mg}$. Because $\mathrm{Mg}$ is required for proper parathyroid hormone function, the effect of supplementing Ca might induce a delayed relapse of the hypocalcemic condition at the end of the supplemental period. Cows supplemented with Ca had a significant but small reduction in $\mathrm{Mg}$ concentrations during the first $4 \mathrm{~d}$ postpartum. Another consequence of excessive $\mathrm{Ca}$ intake is the interference with $\mathrm{Zn}$ absorption (Wood and Zheng, 1997). Zinc is known for its important roles on innate and adaptive immune function. A transient reduction in Zn absorption and availability might impair chemotaxis and killing activity of leukocytes, and production of cytokines by immune cells (Shankar and Prasad, 1998), which might influence susceptibility of cows to diseases.

Others have evaluated the effect of Ca supplementation on $\mathrm{Ca}$ concentrations and incidence of diseases and performance of dairy cows with contrasting results. Stokes and Goff (2001) found that supplementation with 2 doses of $146 \mathrm{~g}$ of $\mathrm{Ca}$ as $\mathrm{Ca}$ propionate did not increase plasma $\mathrm{Ca}$ or glucose concentrations, or af- 
fected milk yield compared with cows not receiving supplemental Ca, but Ca propionate increased concentrations of fatty acids in plasma compared with cows receiving propylene glycol in an equimolar amount of glucose precursor. Melendez et al. (2003) showed that supplementation with $60 \mathrm{~g}$ of $\mathrm{Ca}$ as $\mathrm{CaCl}_{2}$, or $110 \mathrm{~g}$ of $\mathrm{Ca}$ as Ca propionate in combination with $400 \mathrm{~g}$ of propylene glycol had no effect on the incidence of disease, milk yield, or fertility. Oetzel (1996) found that dosing cows with $54 \mathrm{~g}$ of oral $\mathrm{Ca}$ as $\mathrm{CaCl}_{2}$ gel containing 1.5 $\mathrm{g}$ of $\mathrm{Mg}$ and $8.2 \mathrm{~g}$ of $\mathrm{P}$ starting $12 \mathrm{~h}$ before expected calving, at calving, and 12 and $24 \mathrm{~h}$ after calving increased serum tCa concentrations by $0.18 \mathrm{mM}$, but the benefit in serum Ca was observed only in cows of third lactation or greater. Supplementation with oral $\mathrm{Ca}$ reduced incidence of clinical and $\mathrm{SCH}$ and displaced abomasum. Recently, Oetzel and Miller (2012) evaluated the effect of oral administration of $43 \mathrm{~g}$ of $\mathrm{Ca}$ as $\mathrm{CaCl}_{2}$ and $\mathrm{CaSO}_{4}$ at calving and again at 8 to $35 \mathrm{~h}$ later on health and milk yield. The authors showed no differences in serum Ca concentrations, but reduced incidence of health events in cows diagnosed lame in the first 30 DIM. Therefore, the benefits of administering oral $\mathrm{Ca}$ in the first few days postpartum on health seem small and only observed in particular cohorts of cows that likely experience greater risk of clinical and $\mathrm{SCH}$. Cows in the current experiment were fed diets to prevent hypocalcemia, and only multiparous cows showed minor improvements in some aspects of health after $\mathrm{Ca}$ supplementation in early lactation. Further studies are warranted to understand why supplementation with $\mathrm{Ca}$ for at least the first $2 \mathrm{~d}$ postpartum might be detrimental to health in primiparous cows.

\section{CONCLUSIONS}

Oral calcium supplementation with 43 or $86 \mathrm{~g}$ of $\mathrm{Ca}$ as $\mathrm{CaCl}_{2}$ and $\mathrm{CaSO}_{4}$ increased iCa concentrations in blood, but the increase in $\mathrm{iCa}$ and tCa lasted fewer than $2 \mathrm{~h}$ with $43 \mathrm{~g}$ and fewer than $8 \mathrm{~h}$ with $86 \mathrm{~g}$. The increase in blood iCa concentrations after $86 \mathrm{~g}$ of oral $\mathrm{Ca}$ was half in multiparous cows compared with that of primiparous cows. Supplementing cows with oral $\mathrm{Ca}$ reduced the incidence and prevalence of $\mathrm{SCH}$, and these reductions were greater when supplementation was extended to 4 DIM. Despite the positive effects on $\mathrm{SCH}$, oral $\mathrm{Ca}$ increased the incidence of metritis, and the negative effect was observed primarily in primiparous cows considered to be at low risk of metritis. Also, supplementing primiparous cows with $\mathrm{Ca}$ increased morbidity in the first $30 \mathrm{~d}$ postpartum. On the other hand, multiparous cows supplemented with oral Ca had reduced incidence of diseases other than metritis and ketosis. These data refute our original hypothesis and indicate that supplementation with oral Ca used in the current experiment does not reduce the incidence of metritis. Results also suggest that the treatment regimen used for oral Ca supplementation should be avoided in primiparous cows and target only populations at high risk of developing hypocalcemia.

\section{ACKNOWLEDGMENTS}

The authors thank the owners and staff of River Ranch farms (Hanford, CA) for the use of their cows and facilities. We thank Lucas Oliveira, Matheus Pansani, Nienke van de Burgwal, Mariska Bosman, and Patricia Carneiro (University of Florida, Gainesville) for assistance with the field portion of the experiment. Special thanks to Sergei Sennikov (University of Florida, Gainesville) for help with sample processing and analyses. Financial support for this project was provided by a grant from the Southeast Milk Inc. Check-off Program (Belleview, FL).

\section{REFERENCES}

Bronner, F. 1987. Intestinal calcium absorption: Mechanisms and applications. J. Nutr. 117:1347-1352.

Chang, E., S. S. Donkin, and D. Teegarden. 2009. Parathyroid hormone suppresses insulin signaling in adipocytes. Mol. Cell Endocrinol. 307:77-82.

Chapinal, N., M. E. Carson, S. J. LeBlanc, K. E. Leslie, S. Godden, M. Capel, J. E. P. Santos, M. W. Overton, and T. F. Duffield. 2012. The association of serum metabolites in the transition period with milk production and early-lactation reproductive performance. J. Dairy Sci. 95:1301-1309.

Constable, P. D. 2014. Acid-base assessment: When and how to apply the Henderson-Hasselbalch equation and strong ion difference theory. Vet. Clin. North Am. Food Anim. Pract. 30:295-316.

Dai, L. J., G. Ritchie, D. Kerstan, H. S. Kang, D. E. Cole, and G. A. Quamme. 2001. Magnesium transport in the renal distal convoluted tubule. Physiol. Rev. 81:51-84.

Fujita, H., K. Sugimoto, S. Inatomi, T. Maeda, M. Osanai, Y. Uchiyama, Y. Yamamoto, T. Wada, T. Kojima, H. Yokozaki, T. Yamashita, S. Kato, N. Sawada, and H. Chiba. 2008. Tight junction proteins claudin-2 and -12 are critical for vitamin D-dependent $\mathrm{Ca}^{2+}$ absorption between enterocytes. Mol. Biol. Cell 19:1912-1921.

Gochman, N., and J. M. Schmitz. 1972. Application of a new peroxide indicator reaction to the specific, automated determination of glucose with glucose oxidase. Clin. Chem. 18:943-950.

Goff, J. P., and R. L. Horst. 1993. Oral administration of calcium salts for treatment of hypocalcemia in cattle. J. Dairy Sci. 76:101-108.

Goff, J. P., and R. L. Horst. 1994. Calcium salts for treating hypocalcemia: Carrier effects, acid-base balance, and oral versus rectal administration. J. Dairy Sci. 77:1451-1456.

Hines, T. G., N. L. Jacobson, D. C. Beitz, and E. T. Littledike. 1986 Effects of dietary calcium, vitamin $\mathrm{D}_{3}$, and corn supplementation on growth performance and mineral metabolism in young goats fed whole milk diets. J. Dairy Sci. 69:2868-2876.

Höller, H., G. Breves, M. Kocabatmatz, and H. Gerdes. 1988. Flux of calcium across the sheep rumen wall in vivo and in vitro. Q. J. Exp. Physiol. 73:609-618.

Horst, R. L., J. P. Goff, and T. A. Reinhardt. 1990. Advancing age results in reduction of intestinal and bone 1, 25-dihydroxyvitamin D receptor. Endocrinology 126:1053-1057. 
Johnson, M. M., and J. P. Peters. 1993. Technical note: An improved method to quantify nonesterified fatty acids in bovine plasma. J. Anim. Sci. 71:753-756.

Jorgensen, N. A. 1974. Combating milk fever. J. Dairy Sci. 57:933-944.

Khorasani, G. R., R. A. Janzen, W. B. McGill, and J. J. Kennelly 1997. Site and extent of mineral absorption in lactating cows fed whole-crop cereal grain silage of alfalfa silage. J. Anim. Sci. $75: 239-248$.

Martinez, N., C. A. Risco, F. S. Lima, R. S. Bisinotto, L. F. Greco, E. S. Ribeiro, F. Maunsell, K. Galvão, and J. E. P. Santos. 2012. Evaluation of peripartal calcium status, energetic profile, and neutrophil function in dairy cows at low or high risk of developing uterine disease. J. Dairy Sci. 95:7158-7172.

Martinez, N., L. D. P. Sinedino, R. S. Bisinotto, E. S. Ribeiro, G. C. Gomes, F. S. Lima, L. F. Greco, C. A. Risco, K. N. Galvão, D. Taylor-Rodriguez, J. P. Driver, W. W. Thatcher, and J. E. P. Santos. 2014. Effect of induced subclinical hypocalcemia on physiological responses and neutrophil function in dairy cows. J. Dairy Sci. 97:874-887.

McArt, J. A., D. V. Nydam, P. A. Ospina, and G. R. Oetzel. 2011. A field trial on the effect of propylene glycol on milk yield and resolution of ketosis in fresh cows diagnosed with subclinical ketosis. J. Dairy Sci. 94:6011-6020.

McNutt, L. A., C. Wu, X. Xue, and J. P. Hafner. 2003. Estimating the relative risk in cohort studies and clinical trials of common outcomes. Am. J. Epidemiol. 157:940-943.

Melendez, P., G. Donovan, C. A. Risco, R. Littell, and J. P. Goff. 2003 Effect of calcium-energy supplements on calving-related disorders, fertility and milk yield during the transition period in cows fed anionic diets. Theriogenology 60:843-854.

NRC. 2001. Nutrient Requirements of Dairy Cattle. 7th rev. ed. Natl. Acad. Press, Washington, DC.

Oetzel, G. R. 1996. Effect of calcium chloride gel treatment in dairy cows on incidence of periparturient diseases. J. Am. Vet. Med. Assoc. 209:958-961.

Oetzel, G. R., and B. E. Miller. 2012. Effect of oral calcium bolus supplementation on early-lactation health and milk yield in commercial dairy herds. J. Dairy Sci. 95:7051-7065.

Park, A. F., J. E. Shirley, E. C. Titgemeyer, J. M. DeFrain, R. C. Cochran, E. E. Wickersham, T. G. Nagaraja, and D. E. Johnson.
2011. Characterization of ruminal dynamics in Holstein dairy cows during the periparturient period. J. Anim. Physiol. Anim. Nutr. (Berl.) 95:571-582.

Reinhardt, T., J. D. Lippolis, B. J. McCluskey, J. P. Goff, and R. L. Horst. 2011. Prevalence of subclinical hypocalcemia in dairy herds. Vet. J. 188:122-124.

Sampson, J. D., J. N. Spain, C. Jones, and L. Carstensen. 2009. Effects of calcium chloride and calcium sulfate in an oral bolus given as a supplement to postpartum dairy cows. Vet. Ther. 10:131-139.

Seifi, H. A., S. J. Leblanc, K. E. Leslie, and T. F. Duffield. 2011. Metabolic predictors of post-partum disease and culling risk in dairy cattle. Vet. J. 188:216-220.

Shankar, A. H., and A. S. Prasad. 1998. Zinc and immune function: The biological basis of altered resistance to infection. Am. J. Clin. Nutr. 68:447S-463S

Sheldon, I. M., G. S. Lewis, S. LeBlanc, and R. O. Gilbert. 2006 Defining postpartum uterine disease in cattle. Theriogenology 65:1516-1530.

Spiegelman, D., and E. Hertzmark. 2005. Easy SAS calculations for risk or prevalence ratios and differences. Am. J. Epidemiol. 162:199-200.

Stokes, S. R., and J. P. Goff. 2001. Case study: Evaluation of calcium propionate and propylene glycol administered into the esophagus of dairy cattle at calving. Prof. Anim. Sci. 17:115-122.

Thilsing-Hansen, T., R. J. Jørgensen, and S. Østergaard. 2002. Milk fever control principles: A review. Acta Vet. Scand. 43:1-19.

Van Soest, P. J., J. B. Robertson, and B. A. Lewis. 1991. Methods for dietary fiber, neutral detergent fiber and nonstarch polysaccharides in relation to animal nutrition. J. Dairy Sci. 74:3583-3597.

Vieira-Neto, A., F. S. Lima, J. E. P. Santos, R. D. Mingoti, G. S. Vasconcellos, C. A. Risco, and K. N. Galvão. 2016. Vulvovaginal laceration as a risk factor for uterine disease in postpartum dairy cows. J. Dairy Sci. 99:4629-4637. http://dx.doi.org/10.3168/ jds.2016-10872.

Wood, R. J., and J. J. Zheng. 1997. High dietary calcium intakes reduce zinc absorption and balance in humans. Am. J. Clin. Nutr. 65:1803-1809. 